\title{
SISTEM POLITIK DAN PROSES KOMUNIKASI POLITIK
}

\author{
Mirza Shahreza \\ mirzashahreza@gmail.com
}

\begin{abstract}
"Now as in the past it is difficult to separate the quality and cast of political life from the methods of communication that sustain it. But behind the changes wrought by technology, organization, and the scale of politics, there is also a certain sameness. Linked to the communication structures which characterize a society, and in fact inseparable from them, are numerous face-to-face relationships. Much of the political business of the world is still done in such situations, and it would indeed provide a mistaken view of the communication process to concentrate on machines and organizations to the exclusion of the face-to-face groupings which are a prominent feature of all political systems" (Richard R. Fagen, 1966). ${ }^{1}$
\end{abstract}

\section{A. Sifat dari Aspek Politik}

Apakah yang membedakan aspek politik dengan aspek-aspek lain dalam kehidupan masyarakat? Apakah karakteristik-karakteristik dari suatu sistem politik yang membedakan dari sistem ekonomi? Walaupun ahli-ahli politik tidak pernah seluruhnya setuju mengenai jawaban-jawaban atas pertanyaan-pertanyaan tersebut, mereka cenderung untuk menyetujui beberapa masalah pokok. Mungkin tidak seorangpun yang akan berselisih mengenai ide bahwa suatu sistem politik adalah suatu pola hubungan politik. Tetapi, apakah yang disebut hubungan politik ${ }^{2}$

Jawaban atas pertanyaan ini, seperti juga atas banyak pertanyaan lain, walaupun tidak seluruhnya selalu jelas, dapat dijumpai pertama kali dalam karangan Aristoteles, Politics (ditulis antara tahun 335-332 S.M). Di dalam Politics buku pertama, Aristoteles berbeda pendapat dengan orang-orang yang mengatakan bahwa semua jenis kewenangan adalah identik dan mencoba membedakan kewenangan pemimpin politik di dalam suatu asosiasi politik, atau polis, dari bentuk-bentuk kewenangan yang lain, seperti antara majikan dengan budaknya, antara suami terhadap istrinya, dan antara orang tua terhadap anaknya.

Tetapi Aristoteles berpendapat bahwa di dalam asosiasi politik sekurang-kurangnya terdapat aspek yaitu wewenang (authority) atau aturan (rule). Sebenarnya, Aristoteles mendefinisikan polis atau asosiasi politik

\footnotetext{
${ }^{1}$ Richard R. Fagen, 1966. Politics and Communication. Boston: Little, Brown, p. 3. In http://www.arachnis.com/kerryo/ott.htm

${ }^{2}$ Diskusi singkat mengenai pandangan masa kini atas skope ilmu politik, lihat Oran R. Young, System of Political Sciences, Bab I.
} 
sebagai "asosiasi yang mempunyai kedaulatan tertinggi dan mencakup semua", dan mendefinisikan suatu konstitusi atau polity sebagai "organisasi dari suatu polis dalam hubungannya dengan jabatan-jabatan yang umum, tetapi terutama dalam hubungannya dengan jabatan khususnya yang mempunyai kekuasaan tertinggi di dalam semua masalah. ${ }^{3}$ Salah satu dari kriteria Aristoteles mengenai klasifikasi konstitusi-konstitusi adalah porsi penduduk di mana terletak wewenang atau aturan yang terakhir.

Sejak masa Aristoteles, telah di sebarluaskan pengertian bahwa suatu hubungan politik sedikit banyak melibatkan wewenang, aturan, atau kekuasaan. Misalnya, Max Weber (1864-1920) salah seorang sarjana sosial yang sangat berpengaruh, berpendapat bahwa suatu asosiasi harus disebut bersifat politik "jika dan sejauh pelaksanaan aturan-aturannya di selenggarakan secara terus-menerus dalam suatu wilayah melalui penerapan dan ancaman kekerasan fisik oleh staf administratif". Jadi, walaupun Weber menekankan aspek wilayah (teritorial) dari suatu asosiasi politik, sepertinya halnya Aristoteles, dia menekankan bahwa suatu hubungan kekuasaan atau pemerintah adalah salah satu dari karakteristik yang penting. ${ }^{4}$

Untuk mengambil contoh terakhir, Harold Lasswell, seorang sarjana politik yang terkenal, mendefinisikan "ilmu politik, sebagai suatu disiplin empiris, sebagai studi mengenai pembentukan dan pembagian kekuasaan dan suatu tindakan politik, seperti yang dilakukan oleh seorang di dalam perspektif kekuasaan. ${ }^{5}$

\footnotetext{
${ }^{3}$ Ernest Barker, ed., The Politics of Aristoteles (New York: Oxford University Press, 1962), hh.1, 110.

${ }^{4}$ The Theory of Social and Economic Organization, terjemahan A.M. Henderson dan Talcott Parsons (New York: Oxford University Press, 1947), hh. 145-153, 154.

${ }^{5}$ Harold D. Lasweel dan Abraham Kaplan, Power and Society (New Haven: Yale University Press, 1950), hh. Xiv, 240.
} 

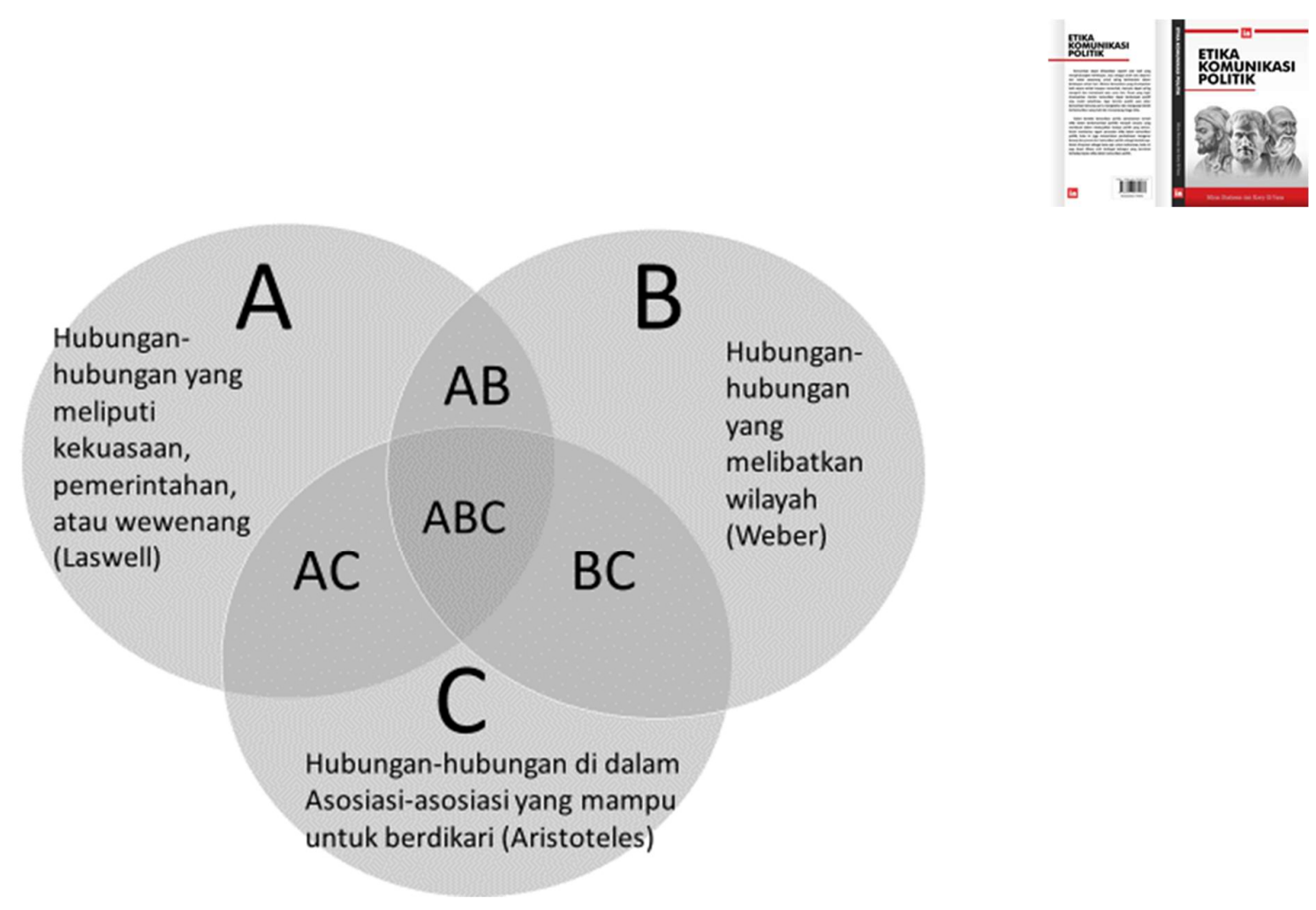

Gambar 2.1: Irisan-irisan pandangan Aristoteles, Weber, dan Laswell ${ }^{6}$

Area kesesuaian dan ketidak-sesuaian dari pendapat-pendapat Aristoteles, Weber dan Laswell mengenai sifat politik bisa dilihat dalam gambar 2.1.

1. Aristoteles, Weber dan Laswell dan hampir seluruh ahli-ahli ilmu politik sepaham bahwa hubungan politik terdapat di dalam bulatan A (sekelompok hubungan yang melibatkan kekuasaan, pemerintah dan wewenang).

2. Secara definitif Laswell menyebut segala sesuatu di dalam bulatan A sebagai bersifat politik.

3. Di lain pihak, Aristoteles dan Weber mendefinisikan "kepolitikan" sebagai sesuatu yang memerlukan tambahan satu atau lebih karakteristik seperti yang tertera dalam bulatan B dan C. Misalnya, daerah dari sesuatu bersifat politik bukanlah segala sesuatu yang terdapat di dalam bulatan A atau segala sesuatu di dalam bulatan B (secara teritorial) tetapi segala sesuatu yang terdapat di bulatan tumpang tindih (irisan) $\mathrm{AB}$, yang melibatkan pemerintahan maupun wilayah.

4. Walaupun Aristoteles kurang jelas dibandingkan Weber atau Lasewll dalam masalah tersebut, pasti dia akan membatasi daerah politik secara lebih ketat misalnya terhadap hubungan-hubungan di dalam asosiasiasosiasi yang mampu untuk berdikari (mandiri) yaitu C. Karena itu bagi Aristoteles "politics" hanya terdapat dalam area ABC.

6 Robert A. Dahl, Modern Political Analysis, Edisi Ketiga (Prentice Hall of India Private Limited, New Delhi, 1978). 
Nyatalah bahwa segala sesuatu yang disebut bersifat politik oleh Aristoteles dan Weber, disebut demikian juga oleh Laswell. Tetapi, Laswell juga menganggap bersifat politik segala sesuatu yang mungkin dianggap tidak bersifat politik oleh Weber dan Aristoteles: firma perdagangan atau serikat buruh misalnya, akan mempunyai aspek-aspek politik. Sebab itu secara berani kita mendefinisikan sesuatu sistem politik sebagai suatu pola hubungan terusmenerus yang melibatkan, sampai di tingkat yang penting, pengawasan, pengaruh, kekuasaan, atau kewenangan. ${ }^{7}$

\section{B. Luasnya Arti Politik}

Tidak dapat disangkal bahwa definisi di atas adalah sangat luas. Sebenarnya, hal itu berarti bahwa banyak asosiasi yang oleh kebanyakan orang biasa dianggap sebagai bersifat politik, ternyata memiliki sistem-sistem kepolitikan: klub-klub pribadi, firma-firma perdagangan (PT, CV), serikat buruh, organisasi-organisasi keagamaan, organisasi sosial suku-suku primitif, clan, bahkan mungkin keluarga-keluarga. Tiga pertimbangan mungkin dapat membantu menjelaskan pemikiran yang tidak biasa tersebut bahwa hampir semua asosiasi kemasyarakatan mempunyai suatu aspek politik:

1. Dalam bahasa biasa kita mengatakan "pemerintahan" dari suatu klub, firma atau corporate dan sebagainya. Malahan, kita mungkin melukiskan “pemerintahan' itu sebagai diktatoral, demokratis, perwakilan atau otoriter; dan kita sering mendengar mengenai "politik" dan "permainan politik (politicking)" berlangsung di dalam asosiasi-asosiasi (lembaga) ini.

2. Suatu sistem politik bukan hanya satu aspek dari sebuah asosiasi. Bilamana kita mengatakan bahwa seseorang adalah dokter, atau guru, atau petani, kita tidak dapat berasumsi bahwa dia hanyalah seorang dokter, atau hanya seorang guru, hanya seorang petani. Tidak ada asosiasi kemanusiaan yang secara ekslusif bersifat politik di dalam semua aspeknya. Seseorang mempunyai banyak hubungan lain selain daripada hubungan kekuasaan dan wewenang, misalnya cinta, penghargaan, dedikasi, kepercayaan, keyakinan, kebencian, dendam dan sebagainya.

3. Definisi kita sebenarnya tidak menyebut sedikitpun mengenai motifmotif kemanusiaan. Dengan definisi itu tidak berarti bahwa di dalam setiap sistem politik orang dipaksa oleh kebutuhan yang timbul dari dirinya sendiri untuk memerintah orang lain, bahwa pemimpin secara bernafsu menginginkan kekuasaan, atau bahwa politik secara inheren merupakan perebutan kekuasaan yang sengit. Hubungan kekuasaan

\footnotetext{
${ }^{7}$ Dalam bab III, kata-kata seperti pengawasan, kekuasaan, pengaruh, dan wewenang disebut Influence term. Konsep pengaruh di definisikan dalam bab tersebut.
} 
bahkan dapat terjadi di antara orang yang tidak bernafsu atas kekuasaan, atau di dalam situasi dimana orang-orang yang sebagian besar haus kekuasaan mempunyai kesempatan sedikit untuk mendapatkannya. Kaum Indian Zuni di Amerika Barat Daya dilaporkan mempunyai perasaan kuat bahwa mencari kekuasaan adalah haram dan pencari kekuasaan tidak harus diberi kekuasaan. ${ }^{8}$ Jadi ketua organisasi adalah mereka yang paling tidak cocok untuk pekerjaan itu, sedangkan yang paling sesuai adalah mereka yang paling sedikit menginginkan pekerjaan tersebut. Hal yang senada juga berdasarkan hadist Rasulullah:

"Dari Abu Musa r.a, katanya: "Aku datang menemui Nabi bersama-sama dua orang laki-laki anak pamanku. Yang seorang berdkata, "ya, Rasulullah! Angkatlah aku jadi Amir (pejabat) di salah satu daerah yang telah dikuasakan Allah kepada Anda." Dan yang seorang lagi berkata pula seperti itu. Jawab Rasulullah saw., "Demi Allah! Aku tidak akan mengangkatkan seserorang untuk memangku suatu jabatan, orang yang meminta-minta supaya dia diangkat, bahkan tidak pula orang yang mengharap-harap (berambisi) untuk $i t u, " 9$

Tetapi apapun bukti dari antropologi atau informasi dari hadist tersebut mungkin yang menjadi masalah pokok adalah: definisi kita yang sangat luas mengenai sistem politik praktis tidak membuat asumsi mengenai sifat dari motif-motif kemanusiaan. Memasuki sistem politik atau gelanggang politik akhirnya seringkali mengesampingkan masalah kemanusiaan dan juga bahkan keimanan. Kekuasaan diburu untuk sekedar memenuhi hawa nafsu bukan karena hati nurani yang bersandarkan kekuasaan adalah amanat Tuhan. Tanda-tanda itupun kalau kita mau menyadari sebenarnya sudah ada sejak manusia lahir dengan simbol tangan yang dikepal dan tangisan seakan suatu pesan (kekuasaan) yang dikirim ke siapapun disekitarnya agar diikuti keinginannya. Pemegang kekuasaan haruslah berawal dari niat yang bersih karena ingin melakukan pengabdian bukan berdasarkan ambisi semata. Sekalipun luas, definisi itu membantu kita untuk membuat beberapa pembedaan tegas yang sering kali kabur di dalam diskursus pada umumnya.

\footnotetext{
${ }^{8}$ Ruth Benedict, Patterns of Culture (Boston: Houston Mifflin Co., 1934)

${ }^{9}$ Shahih Muslim No.: 1791
} 


\section{Sistem Politik dan Sistem Ekonomi}

Penulis sengaja menggandeng dua sistem tersebut karena dewasa ini membahas politik pasti tidak terlepas masalah ekonomi dan bahkan bisa juga terseret ke ranah hukum. Maka buku ini akan menjabarkan kedua sistem tersebut agar lebih komprehensif memahami komunikasi politik.

Analisa politik membahas masalah kekuasaan, pemerintahan, dan kewenangan. Ekonomi mempelajari sumber-sumber yang alam atau produksi dan distribusi dari barang-barang dan jasa-jasa. Politik adalah satu aspek dari bermacam-macam lembaga kemanusiaan; ekonomi adalah aspek yang lain. Sebab itu seorang ahli ekonomi dan seorang ahli politik mungkin bersamasama mempelajari lembaga yang sama, seperti di lembaga Legislatif dan eksekutif yang berkaitan dengan anggaran pendapatan dan belanja negara, kebijakan publik dan sebagainya. Tetapi ahli ekonomi terutama akan memberi perhatian kepada masalah-masalah yang melibatkan kelangkaan dan penggunaan sumber-sumber yang langka, sedangkan ahli politik akan memberikan perhatian terutama kepada masalah-masalah yang melibatkan hubungan kekuasaan, pemerintahan dan wewenang. Tetapi seperti kebanyakan perbedaan antara pokok-pokok dalam masalah intelektual, perbedaan antara politik dan ekonomi sangatlah tipis.

Banyak orang secara ambigu menggunakan istilah-istilah seperti demokrasi, kediktatoran, kapitalisme, dan sosialisme di dalam sistem politik maupun sistem ekonomi. Kecenderungan untuk mengaburkan sistem politik dan sistem ekonomi ini timbul dari kurangnya definisi yang standar, dari ketidak-tahuan mengenai asal usul munculnya istilah-istilah tersebut. Dalam beberapa kasus, dari keinginan untuk menggunakan istilah politik yang sangat menguntungkan ataupun tidak menguntungkan seperti demokrasi atau "kediktatoran" untuk mempengaruhi sikap terhadap sistem-sistem ekonomi.

Haruslah diakui bahwa aspek-aspek politik dari suatu lembaga tidaklah sama dengan aspek-aspek ekonominya. Dari segi sejarah, istilah demokrasi dan kediktatoran biasanya berhubungan dengan sistem politik, sedangkan "kapitalisme" dan sosialisme berhubungan dengan lembaga-lembaga perekonomian. Dari istilah-istilah yang telah digunakan secara historis itu dapat dipahami melalui definisi-definisi seperti di bawah ini:

1. Demokrasi adalah suatu sistem politik di mana kesempatan untuk ikut serta dalam pembuatan dan pengambilan keputusan diberikan secara luas kepada semua warga negara dewasa.

2. Kediktatoran adalah suatu sistem politik dimana kesempatan untuk ikut serta di dalam pengambilan dan pembuatan keputusan terbatas pada sejumlah kecil orang. 
3. Kapitalisme adalah suatu sistem ekonomi dimana kebanyakan kegiatan perekonomian yang besar dilakukan oleh swasta.

4. Sosialisme adalah suatu sistem perekonomian dimana kebanyakan kegiatan yang besar dilakukan oleh agensi-agensi yang dimiliki pemerintah atau masyarakat.

Tiap-tiap pasang dari istilah tersebut, demokrasi-kediktatoran, kapitaslisme-sosialisme, menyatakan secara tidak langsung adanya perbedaan (dichotomy), dan perbedaan-perbedaan sering kali kurang memuaskan. Dalam kenyatannya, banyak sistem politik yang tidak sepenuhnya demokratis atau diktaroral; di dalam banyak negara berbagai kegiatan dari swasta dan pemerintah bergabung satu sama lain. Gabungan-gabungan ini tidak hanya menjelaskan mengenai kelemahan dari dikotomi "kapitalisme-sosialisme", tetapi juga menekankan pada fakta bahwa dari sistem ekonomi untuk tujuantujuan tertentu dan sebagai bagian dari sistem politik untuk tujuan-tujuan yang lain. Perlu diingat adalah bahwa pencampur-bauran istilah-istilah tersebut setelah berguna secara intelektual untuk membedakan beberapa aspek kehidupan seperti "perekonomian" dan aspek-aspek lainnya seperti "politik".

Menurut Rusadi ${ }^{10}$ pengertian sistem adalah: kesatuan (unity) yang terdiri dari bagian-bagian (parts, components, elements, secondary-systems, subsystems) yang secara fungsional terkait satu sama lain dalam ikatan superordinatnya yang menunjukkan suatu gerak dalam rangka mencapai suatu tujuan tertentu. Jadi bisa dikatakan sistem adalah kumpulan elemen-elemen yang behubungan satu sama lain melalui beberapa cara, misalnya: sistem tata surya, tim sepak bola, Lembaga Dewan Perwakilan Rakyat, partai Politik. Selanjutnya ludwig Von Bertalanffy dalam bukunya "General System Theory" atau teori umum sistem yang memaparkan sistem mencakup sifat-sifat konseptual dari berbagai disiplin ilmu. Adapun ciri-ciri dari General System Theory adalah: ${ }^{11}$

1. Interdepedensi (saling ketergantungan);

2. Holism (satu kesatuan yang utuh);

3. Mencari tujuan (goal seeking);

4. Adanya input - proses - output;

5. Adanya kemungkinan entropi (penurunan atau pengurangan sumber daya karena diperlukan untuk melakukan proses);

6. Adanya unsur regulasi (pengaturan);

7. Kegiatan transformasi (perubahan);

8. Adanya hierarki (tingkatan);

9. Munculnya gejala diferensiasi; dan

\footnotetext{
${ }^{10}$ Dalam Dr.H. Nasuka, Teori Sistem (Jakarta: Prenada Media, 2005), hlm 17

${ }^{11} \mathrm{Ibid}, \mathrm{hlm} 16$
} 
10. Adanya unsur equfinality (kesamaan mencapai tujuan akhir).

Di dalam buku pertama yang terbit tahun 1953 (The Political System) Easton mengajukan argumentasi seputar perlunya membangun satu teori umum yang mampu menjelaskan sistem politik secara lengkap. Teori tersebut harus mampu mensistematisasikan fakta-fakta kegiatan politik yang terceraiberai ke dalam suatu penjelasan yang runtut dan tertata rapi. Ronald $\mathrm{H}$. Chilcote menyatakan bahwa pemikiran Easton dapat di rujuk pada tiga tulisannya yaitu The Political System, A Framework for Political Analysis, dan A System Analysis of Political Life. ${ }^{12}$ Easton mendefinisikan politik sebagai proses alokasi nilai dalam masyarakat secara otoritatif. Kata secara otoritatif membuat konsep sistem politik Easton langsung terhubungan dengan negara. ${ }^{13}$ Atas definisi Easton ini Michael Saward menyatakan adanya konsekuensikonsekuensi logis berikut: ${ }^{14}$

1. Bagi Easton hanya ada satu otoritas yaitu otoritas negara;

2. Peran dalam mekanisme output (keputusan dan tindakan) bersifat eksklusif yaitu hanya di tangan lembaga yang memiliki otoritas;

3. Easton menekankan pada keputusan yang mengikat dari pemerintah, dan sebab itu: (a) keputusan selalu dibuat oleh pemerintah yang legitimasinya bersumber dari konstitusi dan (b) Legitimasi keputusan oleh konstitusi dimaksudkan untuk menghindari chaos politik; dan

4. Bagi Easton sangat penting bagi negara untuk selalu beroperasi secara legitimate.

Menurut Chilcote, dalam tulisannya di The Political System, Easton mengembangkan empat asumsi (anggapan dasar) mengenai perlunya suatu teori umum (grand theory) sebagai cara menjelaskan kinerja sistem politik, dan Chilcote menyebutkan terdiri atas: ${ }^{15}$

1. Ilmu pengetahuan memerlukan suatu konstruksi untuk mensistematisasikan fakta-fakta yang ditemukan.

2. Para pengkaji kehidupan politik harus memandang sistem politik sebagai keseluruhan, bukan parsial.

3. Riset sistem politik terdiri atas dua jenis data: data psikologis dan data situasional. Data psikologis terdiri atas karakteristik personal serta motivasi para partisipan politik. Data situasional terdiri atas semua aktivitas yang muncul akibat pengaruh lingkungan. Pengaruh lingkungan ini muncul dari lingkungan fisik (topografi, geografis),

\footnotetext{
${ }^{12}$ Ronald H. Chilcote, Theories of Comparative Politics: The Search for a Paradigm, (Colorado: Westview Press, 1981) hlm. 145-82.

${ }_{13}$ Michael Saward, The Wider Canvas: Representation and Democracy in State and Society dalam Sonia Alonso, John Keane, and Wolfgang Merkel, eds., The Future of Representative Democracy (New York: Cambridge University Press, 2011) hlm.80.

14 Ibid., hlm. 80-83.

${ }^{15}$ Ronald H. Chilcote, Theories ..., op.cit., hlm.146.
} 
lingkungan organis non manusia (flora, fauna), dan lingkungan sosial (rakyat, aksi dan reaksinya).

4. Sistem politik harus dianggap berada dalam suatu disequilibrium (ketidakseimbangan).

Fakta cenderung tumpang-tindih dan tidak teratur tanpa adanya identifikasi. Dari kondisi chaos ini, ilmu pengetahuan muncul sebagai cahaya yang menerangi kegelapan lalu peneliti dapat melakukan klasifikasi secara lebih jelas. Ilmu pengetahuan melakukan pemetaan dengan cara menjelaskan hubungan antar fakta secara sistematis. Politik adalah suatu ilmu pengetahuan dan sebagai ilmu pengetahuan politik memiliki dimensi ontologis, epistemologis, dan aksiologis. Easton memaksudkan teori yang dibangunnya mampu mewakili ketiga unsur ilmiah tersebut.

Dalam konteks bangunan keilmuan, Easton menghendaki adanya suatu teori umum yang mampu mengakomodasi bervariasinya lembaga, fungsi, dan karakteristik sistem politik untuk kemudian merangkum keseluruhannya dalam satu penjelasan umum. Proses kerja sistem politik dari awal, proses, akhir, dan kembali lagi ke awal harus mampu dijelaskan oleh satu kamera yang mampu merekam seluruh proses tersebut. Layaknya pandangan fungsionalis atas sistem, Easton menghendaki analisis yang dilakukan atas suatu struktur tidak dilepaskan dari fungsi yang dijalankan struktur lain.

Easton menghendaki kajian sistem politik bersifat menyeluruh, bukan parsial. Misalnya, pengamatan atas meningkatnya tuntutan di struktur input tidak dilakukan secara parsial melainkan harus pula melihat secara keseluruhan yaitu mengenai keputusan dan tindakan yang dilakukan dalam struktur output. Easton juga memandang sistem politik tidak dapat lepas dari konteksnya. Oleh sebab itu, pengamatan atas suatu sistem politik harus mempertimbangkan kepada pengaruh lingkungan. Pengaruh lingkungan ini disistematisasi ke dalam dua jenis data, psikologis dan situasional. Kendati masih abstrak, Easton sudah mengantisipasi pentingnya data di level individu. Namun, level ini lebih dimaksudkan pada tingkatan unit-unit sosial dalam masyarakat ketimbang perilaku warga negara (seperti umum dalam pendekatan behavioralisme). Easton menekankan pada motif politik saat suatu entitas masyarakat melakukan kegiatan di dalam sistem politik. Menarik pula dari Easton ini yaitu antisipasinya atas pengaruh lingkungan anorganik seperti lokasi geografis ataupun topografi wilayah yang ia anggap punya pengaruh tersendiri atas sistem politik, selain tentunya lingkungan sistem sosial (masyarakat) yang terdapat di dalam ataupun di luar sistem politik. Easton juga menghendaki dilihatnya penempatan nilai dalam kondisi disequilibriun (tidak seimbang). Ketidakseimbangan inilah yang kalau dianalogikan merupakan bahan bakar sehingga sistem politik dapat selalu bekerja. 
Dengan keempat asumsi di atas, Easton paling tidak ingin membangun suatu penjelasan atas sistem politik yang jelas tahapan-tahapannya. Konsepkonsep apa saja yang harus dikaji dalam upaya menjelaskan fenomena sistem politik, lembaga-lembaga apa saja yang memang memiliki kewenangan untuk pengalokasian nilai di tengah masyarakat, merupakan pertanyaan-pertanyaan dasar dari kerangka pikir ini. Chilcote juga menjelaskan bahwa setelah mengajukan empat asumsi seputar perlunya membangun suatu teori politik yang menyeluruh (dalam hal ini teori sistem politik), Easton mengidentifikasi empat atribut yang perlu diperhatikan dalam setiap kajian sistem politik, yang terdiri atas: ${ }^{16}$

\section{Unit-unit dan batasan-batasan suatu sistem politik}

Serupa dengan paradigma fungsionalisme, dalam kerangka kerja sistem politik pun terdapat unit-unit yang satu sama lain saling berkaitan dan saling bekerja sama untuk mengerakkan roda kerja sistem politik. Unit-unit ini adalah lembaga-lembaga yang sifatnya otoritatif untuk menjalankan sistem politik seperti legislatif, eksekutif, yudikatif, partai politik, lembaga masyarakat sipil, dan sejenisnya. Unit-unit ini bekerja di dalam batasan sistem politik, misalnya dalam cakupan wilayah negara atau hukum, wilayah tugas, dan sejenisnya.

\section{Input-output}

Input merupakan masukan dari masyarakat ke dalam sistem politik. Input yang masuk bisa berupa tuntutan dan dukungan. Tuntutan secara sederhana dapat disebut seperangkat kepentingan yang alokasinya belum merata atas sejumlah unit masyarakat dalam sistem politik. Dukungan secara sederhana adalah upaya masyarakat untuk mendukung keberadaan sistem politik agar terus berjalan. Output adalah hasil kerja sistem politik yang berasal dari tuntutan maupun dukungan dari masyarakat. Ada dua output yaitu keputusan dan tindakan yang dilakukan oleh pemerintah. Keputusan adalah pemilihan satu atau beberapa pilihan tindakan sesuai tuntutan atau dukungan yang masuk ke sistem politik. Tindakan adalah implementasi konkrit pemerintah atas keputusan yang dibuat.

\section{Diferensiasi dalam sistem}

Sistem yang baik harus memiliki diferensiasi (pembedaan dan pemisahan) kerja. Di masyarakat modern yang rumit tidak mungkin satu lembaga dapat menyelesaikan seluruh masalah. Misalkan saja dalam proses penyusunan Undang-undang Pemilu, tidak bisa hanya mengandalkan DPR sebagai penyusun utama, melainkan pula harus melibatkan Komisi Pemilihan Umum, lembaga-lembaga pemantau kegiatan pemilu, kepresidenan, ataupun kepentingan-kepentingan partai politik, serta lembaga-lembaga swadaya

\footnotetext{
${ }^{16}$ Ronald H. Chilcote, Theories ..., op.cit., hlm.147.
} 
masyarakat. Sehingga dalam konteks undang-undang pemilu ini, terdapat sejumlah struktur (aktor) yang masing-masing memiliki fungsi sendiri-sendiri.

\section{Integrasi dalam sistem}

Integrasi adalah keterpaduan kerja antar unit yang berbeda untuk mencapai tujuan bersama. Undang-undang Pemilihan Umum tidak akan diputuskan serta ditindaklanjuti jika tidak ada kerja yang terintegrasi antara DPR, Kepresidenan, KPU, Bawaslu, Partai Politik, dan media massa.

Hasil pemikiran tahap pertama Easton adalah sebagai berikut: ${ }^{17}$

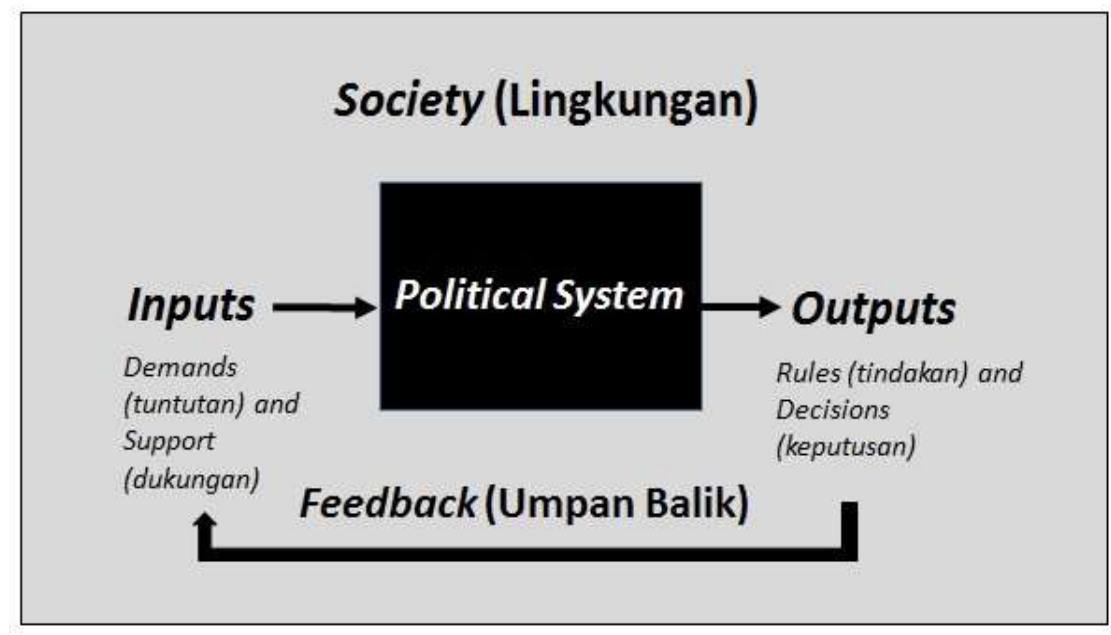

Gambar 2.2: Skema Kerja Sistem Politik Easton

Dalam gambar diatas, Easton memisahkan sistem politik dengan masyarakat secara keseluruhan oleh sebab bagi Easton sistem politik adalah suatu sistem yang berupaya mengalokasikan nilai-nilai di tengah masyarakat secara otoritatif alokasi nilai hanya dilakukan oleh lembaga-lembaga yang memiliki kewenangan yang legitimate (otoritatif) di mata warganegara dan konstitusi. Suatu sistem politik bekerja untuk menghasilkan suatu keputusan (decision) dan tindakan (action) yang disebut kebijakan (policy) guna mengalokasikan nilai. Unit-unit dalam sistem politik menurut Easton adalah tindakan politik (political actions) yaitu kondisi seperti pembuatan UU, pengawasan DPR terhadap Presiden, tuntutan elemen masyarakat terhadap pemerintah, dan sejenisnya. Dalam awal kerjanya, sistem politik memperoleh masukan dari unit input.

Input adalah pemberi makan sistem politik. Input terdiri atas dua jenis: tuntutan dandukungan. Tuntutan dapat muncul baik dalam sistem politik maupun dari lingkungan intrasocietal maupun extrasocietal. Tuntutan ini dapat berkenaan dengan barang dan pelayanan (misalnya upah, hukum ketenagakerjaan, jalan, sembako), berkenaan dengan regulasi (misalnya keamanan umum, hubungan industrial), ataupun berkenaan dengan

\footnotetext{
${ }^{17}$ Skema diambil dari Ronald H. Chilcote, Theories ..., op.cit., hlm.147.
} 
partisipasi dalam sistem politik (misalnya mendirikan partai politik, kebebasan berorganisasi).

Tuntutan yang sudah terstimulasi kemudian menjadi garapan aktoraktor di dalam sistem politik yang bersiap untuk menentukan masalah yang penting untuk didiskusikan melalui saluran-saluran yang ada di dalam sistem politik. Di sisi lain, dukungan (support) merupakan tindakan atau orientasi untuk melestarikan ataupun menolak sistem politik. Jadi, secara sederhana dapat disebutkan bahwa dukungan memiliki dua corak yaitu positif (forwarding) dan negatif (rejecting) kinerja sebuah sistem politik. Setelah tuntutan dan dukungan diproses di dalam sistem politik, keluarannya disebut sebagai output, yang menurut Easton berkisar pada dua entitas yaitu keputusan (decision) dan tindakan (action). Output ini pada kondisi lebih lanjut akan memunculkan feedback (umpan balik) baik dari kalangan dalam sistem politik maupun lingkungan. Reaksi ini akan diterjemahkan kembali ke dalam format tuntutan dan dukungan, dan secara lebih lanjut meneruskan kinerja sistem politik. Demikian proses kerja ini berlangsung dalam pola siklus.

Chilcote menyebutkan bahwa Easton mulai mengembangkan serta merinci konsep-konsep yang mendukung karya sebelumnya ${ }^{18}$ - penjelasanpenjelasannya yang abstrak - dengan coba mengaplikasikannya pada kegiatan politik konkrit dengan menegaskan hal-hal sebagai berikut:19 Masyarakat terdiri atas seluruh sistem yang terdapat di dalamnya serta bersifat terbuka. Sistem politik adalah seperangkat interaksi yang diabstraksikan dari totalitas perilaku sosial, dengan mana nilai-nilai dialokasikan ke dalam masyarakat secara otoritatif. Definisi politik dari Easton; dan lingkungan terdiri atas intrasocietal dan extrasocietal yang penjelasannya adalah sebagai berikut:

1. Lingkungan intrasocietal terdiri atas lingkungan fisik serta sosial yang terletak di luar batasan sistem politik tetapi masih di dalam masyarakat yang sama. Lingkungan intrasocietal terdiri atas:

a) Lingkungan ekologis (fisik, nonmanusia). Misal dari lingkungan ini adalah kondisi geografis wilayah yagng didominasi misalnya oleh pegunungan, maritim, padang pasir, iklim tropis ataupun dingin;

b) Lingkungan biologis (berhubungan dengan keturunan ras). Misal dari lingkungan ini adalah semitic, teutonic, arianic, mongoloid, skandinavia, anglo-saxon, melayu, austronesia, caucassoid dan sejenisnya;

c) Lingkungan psikologis. Misal dari lingkungan ini adalah postcolonial, bekas penjajah, maju, berkembang, terbelakang, ataupun superpower; dan

d) Lingkungan sosial. Misal dari lingkungan ini adalah budaya, struktur sosial, kondisi ekonomi, dan demografis.

\footnotetext{
${ }^{18}$ Pada tulisannya yang lain - A Framework for Political Analysis (1965) dan A System Analysis of Political Life (1965)

${ }^{19}$ Ibid., hlm.148
} 
2. Lingkungan extrasocietal adalah bagian dari lingkungan fisik serta sosial yang terletak di luar batasan sistem politik dan masyarakat tempat sistem politik berada. Lingkungan extrasocietal terdiri atas:

a) Sistem Sosial Internasional. Misal dari sistem sosial internasional adalah kondisi pergaulan masyarakat dunia, sistem ekonomi dunia, gerakan feminisme, gerakan revivalisme Islam, dan sejenisnya, atau mudahnya apa yang kini dikenal dalam terminologi International Regime (rezim internasional) yang sangat banyak variannya.

b) Sistem ekologi internasional. Misal dari sistem ekologi internasional adalah keterpisahan negara berdasar benua (amerika, eropa, asia, australia, afrika), kelangkaan sumber daya alam, geografi wilayah berdasar lautan (asia pasifik, atlantik), isu lingkungan seperti global warming atau berkurangnya hutan atau paru-paru dunia.

c) Sistem politik internasional. Misal dari sistem politik internasional adalah PBB, NATO, ASEAN, ANZUS, Europa Union, kelompok negara-negara Asia Afrika, blok-blok perdaganan dan poros-poros politik khas dan menjadi fenomena di aneka belahan dunia. Termasuk ke dalam sistem politik internasional adalah pola-pola hubungan politik antar negara seperti hegemoni, polarisasi kekuatan, dan tata hubungan dalam lembaga-lembaga internasional.

Seluruh pikiran Easton mengenai pengaruh lingkungan ini dapat dilihat di dalam bagan model arus sistem politik berikut:

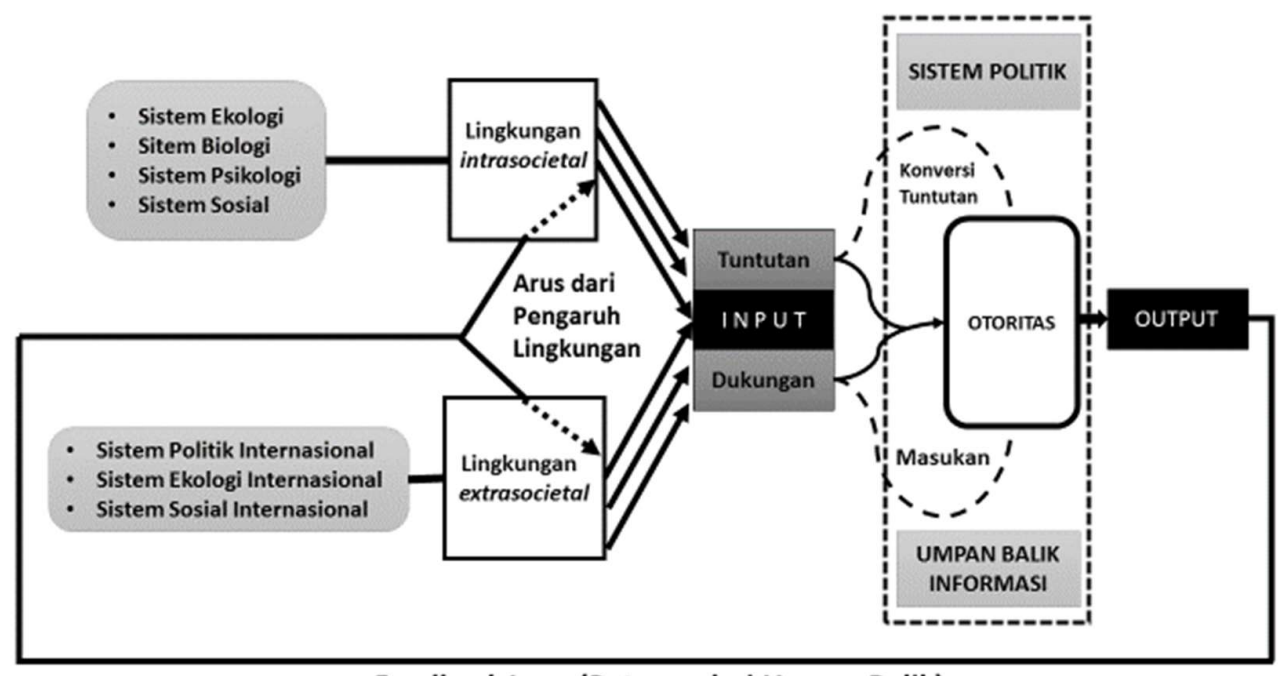

Feedback Loop (Putaran dari Umpan Balik)

Gambar 2.3: Reproduksi Model Arus Sistem Politik Easton

Model arus sistem politik di atas hendak menunjukkan bagaimana lingkungan, baik intrasocietal maupun extrasocietal, mampu mempengaruhi tuntutan dan 
dukungan yang masuk ke dalam sistem politik. Terlihat dengan jelas bahwa skema ini merupakan kembangan lebih rumit dan rinci dari skema yang dibuat Easton dalam karyanya tahun 1953. Keunggulan dari model arus sistem politik ini adalah Easton lebih merinci pada sistem politik pada hakikatnya bersifat terbutka.

Dua jenis lingkungan yang terdiri dari komponen intrasocietal dan extrasocietal mampu mempengaruhi sampai tahap mekanisme input (tuntutan dan dukungan) sehingga struktur proses dan output harus lincah dalam mengadaptasinya. Tuntutan dan dukungan dikonversi di dalam sistem politik yang bermuara pada output yang dikeluarkan oleh Otoritas. Otoritas di sini berarti lembaga yang memiliki kewenangan untuk mengeluarkan keputusan maupun tindakan dalam bentuk policy (kebijakan), bukan sembarang lembaga, melainkan menurut Easton diposisikan oleh negara (state). Output ini kemudian kembali dipersepsi oleh lingkungan dan proses siklus kembali berlangsung.

Gabriel Abraham Almond adalah salah satu pengguna teori sistem politik Easton. Namun, Almond kurang sreg dengan pendekatan Easton yang terlampau abstrak. Almond juga menyayangkan kurangnya perhatian Easton pada kajian-kajian politik dalam skala mikro. Menurut Chilcote, pada tahun 1956 - jadi sekitar tiga tahun setelah David Easton meluncurkan karyanya The Political System tahun 1953 - Gabriel Abraham Almond menerapkan teori sistem tersebut atas sistem politik suatu bangsa sebagai bentuk metode trial and error layaknya sebuah teori. Namun, Almond melakukan sejumlah modifikasi atas teori Easton. Jika Easton membangun suatu grand theory, maka Almond membangun suatu middle-range theory. Secara umum, teori sistem yang dibangun Almond terdiri atas tiga tahap. Pentahapan pemikiran Easton ini mengikuti pendapat Ronald $\mathrm{H}$. Chilcote yang mengacu pada karya-karya penelitian Almond. ${ }^{20}$

Di dalam tulisannya Comparative Polititical System tahun 1956 Almond mengajukan tiga asumsi yang harus dipertimbangkan dalam kajian sistem politik yang terdiri atas:

1. Sistem menandai totalitas interaksi di antara unit-unitnya dan keseimbangan di dalam sistem selalu berubah;

2. Hal penting dalam sistem politik bukan semata-mata lembaga formal, melainkan juga struktur informal serta peran yang dijalankannya; dan

3. Budaya politik adalah kecenderungan utama dalam sistem politik, di mana budaya inilah yang membedakan satu sistem politik dengan sistem politik lain.

Bagi Almond, sistem politik adalah totalitas interaksi antar unit-unit yang ada di dalamnya. Interaksi tersebut tidak hanya sebatas pada lembaga-lembaga (aktor-aktor) politik formal melainkan pula informal. Dapat dibayangkan

\footnotetext{
${ }^{20} \mathrm{Ibid} . \mathrm{hlm} .145-50$.
} 
pengaruh politik struktur-struktur non formal yang dipimpin oleh Kardinal Sin sewaktu perubahan politik Filipina, Uskup Bello saat Timor Timur masih berada di wilayah Indonesia, M. Amien Rais dan K. H. Abdurrachman Wahid yang mewakili Muhammadiyah dan Nahdlatul Ulama dalam pentas politik Indonesia, ataupun pengaruh Pakubuwana secara spiritual bagi politik di tanah Jawa. Easton menghindari kajian atas struktur-struktur seperti ini sementara Almond justru mengapresiasi signifikansinya. Keseimbangan di dalam sistem politik menurut Almond selalu berubah sehingga sistem politik lebih bersifat dinamis ketimbang statis. Perubahan keseimbangan ini tentu saja tidak lepas dari pengaruh lingkungan intrasocietal dan extrasocietal.

Pengaruh tersebut membuat perimbangan kekuatan antar struktur formal berubah dan contoh paling mudah adalah dominannya kekuatan lembaga kepresidenan atas legislatif dan yudikatif di masa pra transisi politik 1998 berganti dengan persamaan dan penyetaraan kekuatan di antara ketiga lembaga tersebut pasca transisi. Kecenderungan orientasi politik individu atas sistem politik - atau biasa disebut budaya politik - juga berbeda baik antar negara atau bahkan di dalam negara itu sendiri. Almond bersama Sidney Verba secara khusus menyelidiki budaya politik ini yang tersusun di dalam buku The Civic Culture: Political Attitudes and Democracy in Five Nations yang terbit tahun 1963. Pada perkembangannya, konsep budaya politik ini semakin populer dan luas digunakan para peneliti di dunia termasuk Indonesia.

Khusus mengenai budaya politik, Almond menyatakan bahwa yang ia maksud dengannya adalah: ${ }^{21}$

1. Seperangkat orientasi politik yang bersifat subyektif dan berlaku di suatu bangsa, atau sub-sub masyarakat yang ada di dalam bangsa tersebut;

2. Budaya politik terdiri atas komponen-komponen kognitif (pengetahuan dan kepercayaan tentang realitas politik), afektif (rasa penghargaan atas politik), dan evaluatif (komitmen atas nilai-nilai politik);

3. Budaya politik adalah hasil sosialisasi politik di masa kanak-kanak, pendidikan, terpaan media, dan akibat sentuhan pengalaman di masa dewasa sehubungan kinerja sosial dan ekonomi yang ditunjukkan pemerintah; dan

4. Budaya politik berdampak atas struktur dan kinerja pemerintah, di mana dampak ini sifatnya lebih cenderung memaksa ketimbang otomatis menentukan struktur dan kinerja pemerintah.

Budaya politik di masing-masing individu sifatnya subyektif. Subyektivitas ini mendorong terdapatnya lebih dari satu macam budaya politik di dalam masyarakat suatu bangsa. Layaknya budaya yang bersifat sosial (budaya daerah atau lokal), budaya politik masyarakat dalam satu negara sangat mungkin berbeda. Sebagian warganegara Indonesia di propinsi

${ }^{21}$ Gabriel A. Almond, The Study of Political Culture dalam Dirk Berg-Schlosse and Ralf Rytlewski, eds., Political Culture in Germany (New York: St. Martin's Press, Inc., 1993) hlm.15. 
Papua tidak seluruhnya memiliki afeksi atas Negara Kesatuan Republik Indonesia, melainkan hanya pada sistem politik lokal yaitu suku-suku atau klan di mana mereka menjadi anggota (komunitas politik lokal), pendukung Organisasi Papua Merdeka ataupun pro-integrasi.

Kembali pada masalah perkembangan pemikiran Gabriel Abraham Almond, bahwa dalam tahap selanjutnya, Almond - kini bersama James Coleman di dalam bukunya The Political of the Developing Areas yang terbit tahun 1963 - berusaha menghindari terjebaknya analisa sistem politik hanya pada kajian kontitusi ataupun lembaga politik formal. Almond dan Coleman kemudian mengarahkannya pada struktur serta fungsi yang dijalankan masing-masing unit politik dalam sistem politik. Dengan demikian, Almond memperkenalkan konsep fungsi guna menggantikan konsep power, sementara konsep struktur digunakannya untuk mengganti konsep lembaga politik formal.

Almond dalam bukunya "The Study of Political Culture" menegaskan bahwa sistem politik memiliki empat karakteristik yang bersifat universal. Keempat karakteristik ini berlaku di negara manapun dan terdiri atas premispremis:22

1. Setiap sistem politik memiliki struktur-struktur politik;

2. Fungsi-fungsi (dari setiap struktur) yang sama dapat ditemui di setiap sistem politik;

3. Setiap struktur politik bersifat multifungsi; dan

4. Setiap sistem politik telah bercampur dengan budaya politik (yang dianut warganegara masing-masing).

Setelah mengajukan keempat premis tersebut, Almond memodifikasi struktur input serta output Easton dan hasilnya adalah Almond berhasil memperjelas abstraknya Easton dalam bentuk yang lebih mendetail dalam menjelaskan masalah fungsi input dan output sistem politik sebagai berikut: ${ }^{23}$

\section{Fungsi Input terdiri atas:}

a) Sosialisasi dan rekrutmen politik. Fungsi sosialisasi dan rekrutmen politik selanjutnya ditempatkan Almond sebagai fungsi pemeliharaan sistem politik. Sosialisasi kebanyakan dilakukan oleh partai politik dan lembaga pemerintah seperti Komisi Pemilihan Umum (KPU).

b) Artikulasi kepentingan. Struktur yang menjalankan fungsi artikulasi kepentingan adalah kelompok-kelompok kepentingan yang terorganisir yang meliputi tipe: (a) Institutional; (b) Non-Associational;

(c) Anomic; dan (d) Associational.

22 Ronald H. Chilcote, Theories ..., op.cit., hlm. 163.

${ }^{23}$ Jagdish Chandra Johari, Comparative Politics, 8th Edition (New Delhi: Sterling Publishers Private Limited, 2008) hlm. 75-7. 
c) Agregasi (pengelompokan) kepentingan. Jalannya fungsi ini dipengaruhi oleh dua hal yaitu sistem kepartaian yang berlaku di suatu negara dan penampilan fungsi-fungsi agregatif. Sistem kepartaian (menurut Almond) misalnya Authoritarian, Dominant-Authoritarian, Competitif, dan Competitive Multi-party. Penampilan fungsi-fungsi agregatif misalnya tawar-menawar yang sifatnya pragmatis atau sekular, cenderung berorientasi nilai absolut, dan bersifat tradisi ataupun partikularistik. Pengelompokan contohnya pada saat terbentuknya kelompok Poros Tengah di DPR RI (1999) dan dua koalisi yaitu Koalisi Merah Putih (KMP) dan Koalisi Indonesia Hebat (KIH) pada 2014.

d) Komunikasi politik. Guna membanding pola komunitasi politik antar sistem politik, Almond mengajukan empat parameter yaitu: (1) Homogenitas informasi politik yang tersedia; (2) Mobilitas informasi (vertikal atau horisontal; (3) Nilai informasi; dan (4) Arah dari arus informasi yang berkembang (komunikator atau komunikan).

\section{Fungsi output terdiri atas :}

a) Pembuatan peraturan. Berdasarkan tuntutan dan dukungan serta aneka pengaruh lingkungan intrasocietal dan extrasocietal, input berusaha diterjemahkan menjadi kebijaksanaan umum (policy).

b) Penerapan peraturan. Ketika policy sudah terbentuk, hal yang harus dilakukan adalah melakukan tindak administrasi guna mengimplementasikannya pada ranah publik.

c) Pengawasan peraturan. Ada lembaga khusus yang melakukan pengawasan dan menyelesaikan persengketaan dalam hal pembuatan dan pelaksanaan peraturan.

Menurut Chilcote, setelah merevisi teori sistem politik dari David Easton, Almond meringkas pola pikir sistem politiknya ke dalam skema berikut:24

\footnotetext{
${ }^{24}$ Ronald H. Chilcote, Theories ..., op.cit., h. 167
} 


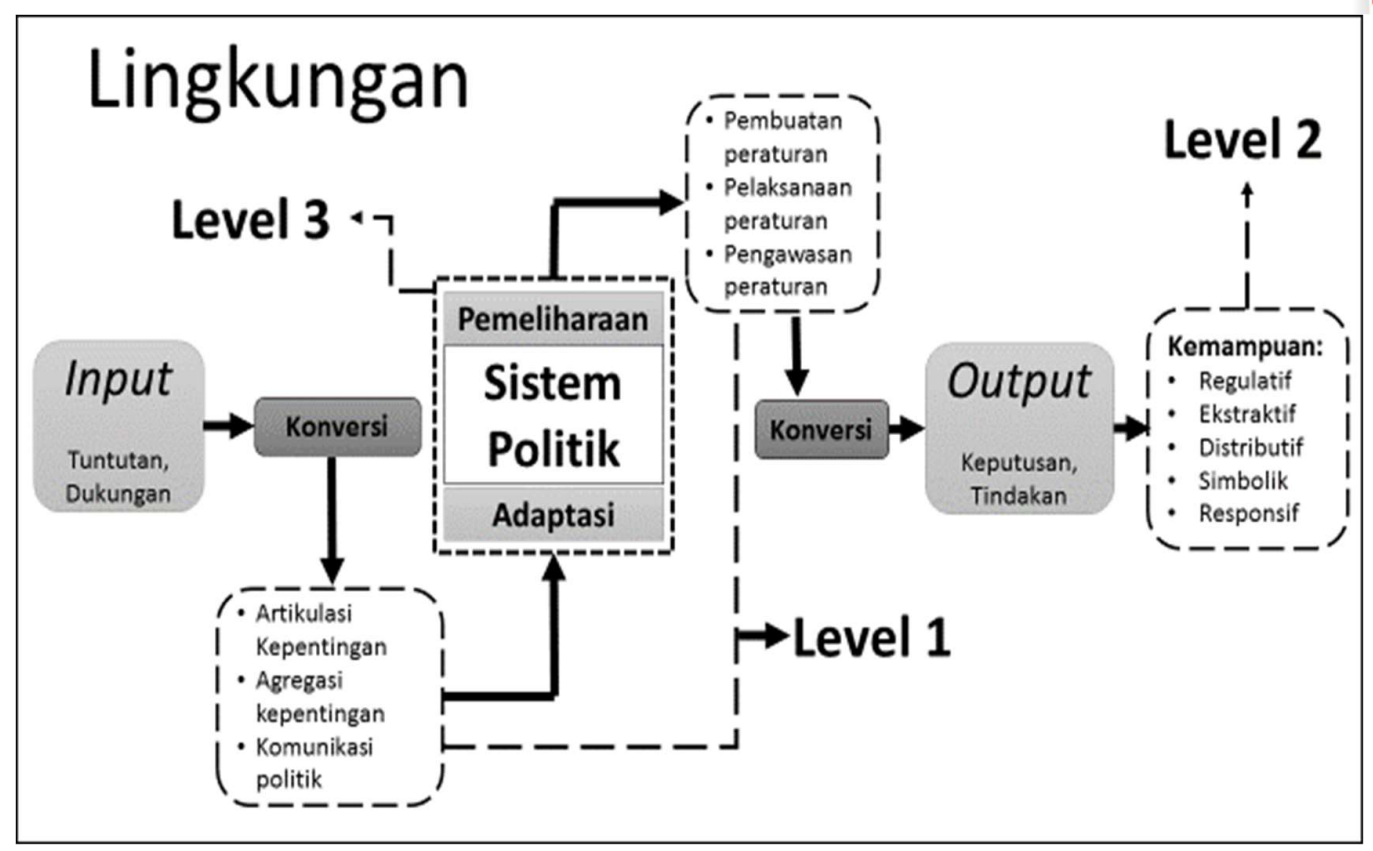

Gambar 2.4 Diagram Sistem Politik Almond dan Level-level Fungsi (modifikasi)

Di level fungsi input, sosialisasi dan rekrutmen politik meliputi rekrutmen individu dari aneka kelas masyarakat, etnik, kelompok, dan sejenisnya untuk masuk ke dalam partai politik, birokrasi, lembaga yudisial, dan sebagainya. Dalam perkembangan pemikirannya kemudian, Almond memasukkan sosialisasi dan rekrutmen politik ke dalamfungsi konversi. Artikulasi kepentingan merupakan ekspresi kepentingan dan tuntutan politik untuk melakukan tindakan.

Melalui skema di atas - masih menurut Chilcote - Almond membagi sistem politik ke dalam tiga level. Level pertama terdiri atas enam fungsi konversi yaitu:

1. Artikulasi kepentingan (penyampaian tuntutan dan dukungan);

2. Agregasi kepentingan (pengelompokan ataupun pengkombinasian aneka kepentingan ke dalam wujud rancangan undang-undang);

3. Komunikasi politik; (penyampaian pesan dari sumber ke penerima dalam konteks politik);

4. pembuatan peraturan (pengkonversian rancangan undang-undang menjadi undang-undang atau peraturan lain yang sifatnya mengikat);

5. Pelaksanaan peraturan (penerapan aturan umum undang-undang dan peraturan lain ke tingkat warganegara), dan;

6. Pengawasan peraturan (pengawasan jalannya penerapan undangundang di kalangan warganegara).

Dari level-level yang telah di paparkan diatas terdapat adanya fungsi nomor satu hingga tiga yang berhubungan dengan tuntutan dan dukungan yang masuk melalui mekanisme input sementara fungsi nomor empat hingga enam 
berada di sisi keluaran berupa keputusan serta tindakan. Mengenai penjelasan atas tuntutan (demands) dan dukungan (support) yang dimaksud Almond, Jagdish Chandra Johari memetakannya ke dalam tiga arus penjelasan yaitu input, konversi, dan output. ${ }^{25}$

\section{Tuntutan dan Dukungan}

Tuntutan adalah bahan mentah (raw material) yang kemudian diolah sistem politik menjadi keputusan. Tuntutan adalah berada di struktur input dan diciptakan oleh individu maupun kelompok yang memainkan peran tertentu di dalam sistem politik. Tuntutan juga sifatnya sangat beragam dan setiap tuntutan punya dampak yang berbeda atas sistem politik. Tuntutan akan menjadi masukkan bisa jadi suatu desakan yang berasal dari lingkungan intrasocietal maupun extrasocietal, yang variannya sebagai: ${ }^{26}$

a) Tuntutan atas komoditas dan pelayanan, misalnya jaminan sosial, kelancaran bertransportasi, kesempatan menikmati pendidikan, peningkatan pelayanan kesehatan, pembangunan saluran irigasi, ataupun pelayanan birokrasi negara yang tidak berbelit. Konversi atas tuntutan ini adalah dalam bentuk artikulasi kepentingan (atau tuntutan). Output berlingkup pada kemampuan ekstraktif semisal pengenaan pajak untuk membiayai jaminan sosial, peningkatan retribusi kendaraan untuk membangun jalan-jalan layang, penaikan pajak perusahaan untuk meningkatkan pelayanan kesehatan, pengundangan investor asing untuk membangun saluran irigasi, dan peningkatan hutang negara untuk menaikkan gaji Pegawai Negeri Sipil.

b) Tuntutan untuk mengatur sejumlah perilaku warganegara seperti penertiban ormas-ormas parayudisial, pembersihan tindak korupsi pejabat negara, atau kompilasi hukum Islam ke dalam hukum publik. Output berupa kemampuan regulatif yang mengatur perilaku individu, kelompok, ataupun warganegara secara keseluruhan. Konversi atas tuntutan ini berupa integrasi atau kombinasi kepentingan ke dalam rancangan undang-undang (agregasi).

c) Tuntutan untuk berpartisipasi dalam sistem politik seperti hak pilih, hak dipilih, mendirikan organisasi politik, melakukan lobby, atau menjalin kontak dengan pejabat-pejabat publik. Konversi atas tuntutan ini adalah mengubah rancangan undang-undang menjadi peraturan yang lebih otoritatif. Output konversi misalnya kemampuan regulatif misalnya penetapan kuota caleg $30 \%$ perempuan dalam undangundang pemilihan umum.

\footnotetext{
${ }^{25}$ J.C. Johari, Comparative ..., op.cit. p. 122-3. Penulis ini memuatnya ke dalam tabel, dan di buku ini diparafrase menjadi paragraf dengan tambahan seperlunya. ${ }^{26}$ Ibid.
} 
d) Tuntutan yang sifatnya simbolik meliputi penjelasan pejabat pemerintah atas suatu kebijakan, keberhasilan sistem politik mengatasi masalah, upaya menghargai simbol-simbol negara (lagu kebangsaan, lambang), ataupun upacara-upacara hari besar nasional. Konversi atas tuntutan jenis ini misalnya dibuatnya ketentuan umum yang mengatur implementasi setiap tuntutan yang sifatnya simbolik. Outputyang sifatnya simbolik termasuk penegasan sistem politik atas simbol-simbol negara, penegasan nilai-nilai yang dianut (di Indonesia adalah Pancasila), serta penjelasan rutin dari pejabat negara atas isu-isu yang kontroversial dan menyita perhatian publik.

Jika tuntutan adalah bahan mentah untuk memproduksi keputusan-keputusan politik, maka dukungan berkisar upaya mempertahankan atau menolak keberlakuan sebuah sistem politik. Tanpa dukungan sistem politik kehilangan legitimasi dan otoritasnya. Selanjutnya dukungan tersebut terdiri atas: ${ }^{27}$

a) Dukungan material warganegara bisa berupa kemauan membayar pajak atau peran aktif mereka dalam program-program yang dicanangkan pemerintah (misalnya program kebersihan lingkungan, penanaman sejuta pohon). Konversi dukungan ini adalah ajudikasi peraturan di tingkat individu yaitu upaya penerapan sanksi bagi yang tidak menurut pada program pemerintah serta kemampuan simbolik pemerintah untuk melakukan himbauan agar publik tertarik memberi dukungan pada pemerintah.

b) Dukungan untuk taat pada hukum serta peraturan-peraturan yang dibuat oleh pemerintah. Konversi dukungan ini berupa pentransmisian informasi yang berkaitan dengan ketaatan warganegara pada hukum di sekujur struktur sistem politik, antar sistem politik, serta lingkungan extrasocietal-nya.

c) Dukungan untuk berpartisipasi dalam pemilu, ikut serta dalam organisasi politik, ataupun mengadakan diskusi tentang politik.

d) Dukungan dalam bentuk tindakan untuk mempertahankan otoritas publik, upacara, serta simbol-simbol negara. Misalnya mengamalkan Pancasila, menyayangi sarana-sarana publik (alat transportasi umum, telepon umum, gedung-gedung pemerintah), menentang penggantian ideologi Pancasila dengan ideologi lain, mencuci bendera merah putih yang terkotori debu dan hujan asam, mensosialisasikan peran vital Pancasila dalam mengikat integrasi nasional Indonesia.

\section{Kapabilitas Sistem Politik}

Level kedua dari aktivitas sistem politik terletak pada fungsi-fungsi kemampuan. Kemampuan suatu sistem politik menurut Almond terdiri atas

27 Ibid. 
kemampuan regulatif, ekstraktif, distributif, simbolis, dan responsif. Kemampuan ekstraktif adalah kemampuan atau potensi dari suatu sistem politik dalam mendayagunakan sumber-sumber daya material ataupun manusia baik yang berasal dari lingkungan domestik (dalam negeri) maupun internasional. ${ }^{28}$ Dalam hal kemampuan ekstraktif ini Indonsia lebih besar ketimbang Timor Leste, karena faktor sumber daya manusia maupun hasilhasil alam yang dimilikinya. Namun, kemampuan Indonesia dalam konteks ini lebih kecil ketimbang Cina. Adapun penjelasan kemampuan suatu sistem politik adalah sebagai berikut:

a) Kemampuan regulatif adalah kemampuan sistem politik dalam mengendalikan perilaku serta hubungan antar individu ataupun kelompok yang ada di dalam sistem politik. Dalam konteks kemampuan ini sistem politik dilihat dari sisi banyaknya regulasi (undang-undang dan peraturan) yang dibuat serta intensitas penggunaannya karena undang-undang dan peraturan dibuat untuk dilaksanakan bukan disimpan di dalam laci pejabat dan warganegara. Selain itu, kemampuan regulatif berkaitan dengan kemampuan ekstraktif dimana proses ekstraksi membutuhkan regulasi.

b) Kemampuan ekstraktif adalah kemampuan sistem politik dalam mendayagunakan sumber-sumber daya material ataupun manusia baik yang berasal dari lingkungan domestik (dalam negeri) maupun internasional

c) Kemampuan distributif adalah kemampuan sistem politik dalam mengalokasikan barang, jasa, penghargaan, status, serta nilai-nilai (misalnya seperti nilai yang dimaksud Lasswell) ke seluruh warganegaranya. Kemampuan distributif ini berkaitan dengan kemampuan regulatif karena untuk melakukan proses distribusi diperlukan rincian, perlindungan, dan jaminan yang harus disediakan sistem politik lewat kemampuanregulatif-nya.

d) Kemampuan simbolik adalah kemampuan sistem politik untuk secara efektif memanfaatkan simbol-simbol yang dimilikinya untuk dipenetrasi ke dalam masyarakat maupun lingkungan internasional. Misalnya adalah lagu-lagu nasional, upacara-upacara, penegasan nilainilai yang dimiliki, ataupun pernyataan-pernyataan khas sistem politik. Simbol adalah representasi kenyataan dalam bahasa ataupun wujud sederhana dan dapat dipahami oleh setiap warga negara. Simbol dapat menjadi basis kohesi sistem politik karena mencirikan identitas bersama. Salah satu tokoh politik Indonesia yang paling mahir dalam mengelola kemampuan simbolik ini adalah Sukarno yang terkenal dengan sebutan bapak Proklamator ini mempunyai kemampuan sebagai orator ulung yang mengobarkan semangat rakyat dalam rapatrapat raksasa dan pemerintah Indonesia di masa Orde Baru, yaitu

\footnotetext{
${ }^{28}$ Herbert Victor Wiseman, Political Systems: Some Sociological Approaches (London: Routledge, 1966) hlm.157-8. Uraian mengenai kelima kemampuan sistem politik dalam buku ini mengikuti sumber ini.
} 
Suharto dengan gaya kepemimpinan yang sering disebut "The Smiling General" terkenal dengan sebutan bapak Pembangunan.

e) Kemampuan responsif adalah kemampuan sistem politik untuk menyinkronisasi tuntutan yang masuk melalui input dengan keputusan dan tindakan yang diambil otoritas politik di lini output. Di Indonesia tuntutan yang sangat bersejarah adalah pada saat tuntutan rakyat ingin Presiden Suharto turun jabatan, setelah 32 tahun berkuasa bukan hal yang sederhana. Merespon gerakan massa yang dikomandoi oleh elemen-elemen mahasiswa, aktifis dan beberapa tokoh nasional tersebut akhirnya berujung mundurnya Suharto sebagai bentuk sinkronisasi dari tuntutan rakyat pada saat itu. Lalu pada masa pemerintahan SBY juga mampu melakukan sinkronisasi antara tuntutan pihak Gerakan Aceh Merdeka dengan keputusan untuk melakukan perundingan dengan mereka serta melaksanakan kesepakatan Helsinki hasil mediasi. Sinkronisasi ini membuat tuntutan dari Aceh tidak lagi meninggi kalau bukan sama sekali lenyap. Kemampuan responsif juga ditunjukkan pada era pemerintahan Jokowi, terutama terhadap opini publik, baik di media massa dan media sosial yang memanas terhadap isu tertentu. Seperti tuntutan penurunan harga BBM yang mengakibatkan terjadi 4 kali perubahan sejak menjabat presiden, begitu pula pada kasus pencabutan izin ojek online oleh Mentri Perhubungan Ignasius Jonan dan langsung direspon melalui twitter oleh Jokowi dengan twitnya, "Saya segera memanggil Menhub. Ojek dibutuhkan rakyat. Jangan karena aturan rakyat jadi susah. Harusnya ditata. $J K W^{\prime \prime}{ }^{29}$ Di era digital, opini publik bisa dipantau dan diamati di sosial media dengan istilah netizen sehingga dapat dengan cepat diamati dan direspon oleh elite politik.

Almond menyebutkan bahwa pada negara-negara demokratis, output dari kemampuan regulatif, ekstraktif, dan distributif lebih dipengaruhi oleh tuntutan dari kelompok-kelompok kepentingan sehingga dapat dikatakan bahwa masyarakat demokratis memiliki kemampuan responsif yang lebih tinggi ketimbang masyarakat non demokratis. Sementara pada sistem totaliter, output yang dihasilkan kurang responsif pada tuntuan, perilaku regulatif bercorak paksaan, serta lebih menonjolkan kegiatan ekstraktif dan simbolik maksimal atas sumber daya masyarakatnya.

\section{Pemeliharaan Sistem Politik}

Level ketiga ditempati oleh fungsi maintenance (pemeliharaan) dan adaptasi. Kedua fungsi ini ditempati oleh sosialisasi dan rekrutmen politik. Teori sistem politik Gabriel A. Almond ini kiranya lebih memperjelas maksud dari David Easton dalam menjelaskan kinerja suatu sistem politik. Melalui

${ }^{29}$ http://www.tribunnews.com/nasional/2015/12/18/jokowi-merespon-ojek-online-netizen-kritikmenteri-panggil-dan-setrap-pak, diakses tanggal 26 April 2016, jam 06.28 
Gabriel A. Almond, pendekatan struktural fungsional mulai mendapat tempat di dalam analisis kehidupan politik suatu negara.

\section{Sistem dan Sub-Sistem}

Suatu kumpulan elemen-elemen yang berhubungan satu sama lain melalui cara beberapa cara dapat dianggap sebagai sebagai suatu system misalnya: tata surya, sebuah tim sepakbola, Dewan Perwakilan Rakyat (DPR), dan juga partai politik. ${ }^{30}$ Berkaitan dengan sistem politik, ada beberapa hal penting yang harus kita ketahui dalam suatu sistem agar dapat membedakan antara sistem politik dan sistem social, yaitu:

1. Untuk menganggap sesuatu sebagai suatu system dalam suatu cara penglihatan yang abstrak (atau seperti dikatakan oleh beberapa ahli, suatu cara analitis) terdapat sesuatu yang kongkrit. Sebab itu seseorang haruslah berhati-hati untuk tidak mengaburkan sesuatu yang kongkrit dengan "sistem" yang analitis. Suatu sistem adalah suatu aspek dari sesuatu yang dalam beberapa hal merupakan abstraksi dari kenyataan untuk tujuan-tujuan analitis; sistem peredaran darah pada mahluk hidup atau sistem sosial dari koloni hewan di alam liar, seperti koloni rusa, koloni lebah, semut dan sebagainya.

2. Untuk menentukan apa yang terdapat di dalam suatu sistem dan apa yang terdapat di luarnya, kita perlu untuk menentukan batas-batas dari sitem itu. Kadang-kadang upaya ini mudah seperti menetapkan batasbatas system tata surya atau dalam hal memamahi teritorial suatu negara yang mempunyai batas-batas wilayah. Sistem politik bisa dibatasi melalui sebuah negara secara internal dan di luar suatu negara tersebut berarti di luar sistem negera tersebut.

3. Suatu sistem dapat menjadi suatu elemen atau suatu sub-sistem, dari sistem yang lain. Bumi adalah sub-sistem dari sistem tata-surya kita, yang merupakan sub-sistem dari bimasakti kita dimana bimasakti itu merupakan sub-sistem dari alam semesta komisi-komisi di DPR merupakan sub-sistem dari lembaga DPR, kementrian dan departemen adalah sub-sistem dari pemerintah (eksekutif), dan seterusnya.

4. Sesuatu mungkin menjadi suatu sub-sistem dari dua atau lebih sistemsistem yang berbeda yang bisa saja saling tumpang tindih (overlap), contoh seorang seorang dosen bisa jadi menjadi anggota sebuah asosiasi, anggota partai dan juga menjadi ketua Rukun Tetangga (RT).

\section{E. Sistem-Sistem Politik dan Sistem-Sistem Sosial}

\footnotetext{
${ }^{30}$ Untuk memahami mengenai "system", sifat umum teori system, dan kegunaan pendekatan (approach) sistem di dalam ilmu politik, maka bisa dilihat dalam buku Young, "System of Political Science Bab I dan Bab II. Upaya yang ektensif untuk menerapkan teori system ke dalam ilmu politik terdapat dalam dua buku David Easton: A Framework for Political Analisys (Englewood Cliffs, N.J.: Prentice-Hall, 1965) dan A System Analysis of Political Life (New York, John Wiley \& Sons, 1965).
} 
Apakah yang disebut masyarakat demokratis? Masyarakat bebas? Suatu masyarakat sosial? Suatu masyarakat otoriter suatu masyarakat internasional? Dengan cara bagaimana suatu sistem social dibedakan dari suatu sistem politik?

Pertanyaan-pertanyaan diatas sukar untuk dijawab terutama karena istilah "masyarakat" dan "sistem sosial" digunakan secara longgar bahkan juga oleh ahli-ahli bidang ilmu sosial. Secara umum istilah "masyarakat" cenderung menjadi inklusif; hubungan ekonomi dan politik merupakan jenis hubungan sosial yang khas. Walaupun "sistem social" kadang-kadang memberikan pengertian yang lebih khusus, hal ini juga merupakan konsep yang sangat luas. Talcott Parsons, seorang ahli sosiologi Amerika mendefinisikan suatu sistem sosial dengan tiga karakteristik:

1. Terdapat dua atau lebih orang yang berinteraksi;

2. Di dalam tindakan-tindakan mereka, mereka juga memperhatikan bagaimana yang lain bertindak;

3. Kadang-kadang mereka bertindak dalam rangka mengejar tujuan bersama.

Jadi, suatu sistem sosial merupakan suatu jenis orde yang sangat inklusif.

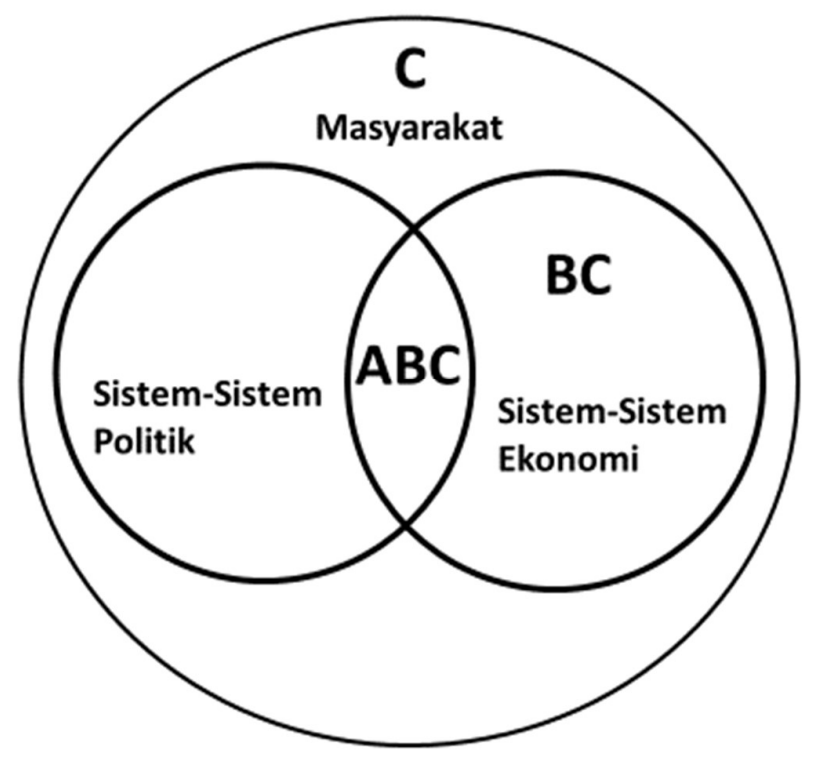

Gambar 2.4: Sistem-sistem politik dan ekonomi dalam Sistem Sosial

Menurut Parsons suatu sistem politik atau sistem ekonomi merupakan bagian-bagian, aspek-aspek, atau sub-sistem-subsistem dari suatu sistem sosial. Cara memandang masalah ini digambarkan dalam gambar 2.4, dimana AC menggambarkan kumpulan dari seluruh sub-sistem politik dan ABC menggambarkan subsistem - subsistem yang dapat dianggap sebagai 
subsistem ekonomi atau politik tergantung kepada aspek mana yang lebih kita pentingkan. Contoh mengenai ABC seperti penetapan Anggaran Pendapatan dan Belanja Negara (APBN), masalah PT. Freeport, masalah inflansi, kenaikan harga BBM dan sebagainya yang merupakan persinggungan masalah politik dan ekonomi yang akan mempengaruhi sistem sosial di masyarakat, sebagai contoh kegaduhan politik parlemen (DPR) seperti kasus "papa minta saham" (2015), kenaikan harga BBM yang merupakan kebijakan (output) dari salah satu sistem politik berakibat reaksi dari masyarakat seperti demonstrasi dan banjir opini di media sosial seperti hashtag (tanda pagar: \#) yang menjadi trending topic dan ini adalah fenomena yang menjadi perhatian dari kekuatankekuatan politik suprastruktur saat ini.

Jadi, suatu masyarakat demokratis dapat di definisikan sebagai suatu sistem sosial yang tidak hanya mempunyai (sub) sistem politik demokratis tetapi juga sejumlah sub-sistem lain yang bekerja untuk menyumbangkan sesuatu yang memperkuat proses politik demokratis secara langsung atau tidak langsung. Sebaliknya, penting suatu masyarakat otoriter menurut definisinya, akan berisikan banyak sub-sistem seperti keluarga, sekolahsekolah, lembaga-lembaga keagamaan, dan lainnya yang kesemuanya bertindak untuk memperkuat proses politik otoriter. Sebagai contoh dibawah ini:

- Di dalam bukunya yang terkenal, "Democrasy in Amerika" (1835-1840), penulis Prancis Alexis de Tocqueville menyajikan daftar mengenai sejumlah "sebab-sebab pokok yang menimbulkan kecendrungan untuk melanggengkan republik yang demokratis di Amerika serikat". Daftarnya tidak hanya meliputi struktur konstitusional tetapi juga mengenai tidak adanya organisasi kemiliteran yang besar dan kuat, persamaan dalam kondisi sosial dan ekonomi, perekonomian pertanian yang makmur, dan kebiasaan, adat istiadat serta kepercayaan agama orang-orang Amerika. ${ }^{31}$ Dalam pandangan Tocqueville prospekprospek dari suatu sistem politik demokrasi yang sehat di Amerika Serikat sangat diperkuat oleh kenyataan bahwa suatu konstitusi yang sangat demokratis telah diperkuat oleh banyak aspek kemasyarakatan yang lain. Sebab itu, masyarakat Amerika dapat di sebut sebagai suatu masyarakat demokratis.

- Sebaliknya, banyak pengamat merasa pesimis mengenai masa depan demokrasi di Jerman setelah perang dunia II, karena mereka yakin bahwa banyak aspek dalam masyarakat Jerman yang sangat otoriter dan cenderung untuk merusak hubungan-hubungan politik yang demokratis. Mereka terutama memberi perhatian kepada kecendrungan yang meluas di dalam semua jenis lembaga kemasyarakatan untuk menganut suatu pola dominasi dan kepatuhan yang kuat seperti dalam keluarga, sekolah-sekolah, gereja-gereja, perdagangan, dan semua hubungan antara pegawai tinggi pemerintahan baik polisi atau pegawai

${ }^{31}$ Alexis de Tocqueville, Democracy in America, Vol.1 (New York: Vintage Books, 1955), hlm. 292-342. 
negeri dengan rakyat biasa. Kenyataan bahwa demokrasi politik juga terdapat di dalam suatu lingkungan kemasyarakatan yang otoriter tidaklah menguntungkan bagi masa depan demokrasi di Jerman. Sejumlah pengamat masa kini merasa lebih optimis mengenai masa depan demokrasi politik di Jerman karena merek melihat bukti bahwa sifat otoriter di dalam beberapa lembaga kemasyarakatan lainnya telah bekurang.

\section{F. Komunikasi Politik dalam Sistim Politik}

Dalam wilayah ilmu terapan (das sein), komunikasi politik sangat bergantung pada sistem politik tempat komunikasi diterapkan. Secara universal sistem politik menampakkan karakter sama yaitu terdiri dari dua sub-sistem, yaitu: ${ }^{32}$

1. Sub-sistem suprastruktur (the governmental political sphere), sebagai sarana kehidupan politik pemerintah, dan

2. Sub-sistem infrastruktur yaitu suasana kehidupan politik masyarakat (the socio political spare).

Kedua kondisi tersebut, saling berpengaruh secara berkaitan, sehingga suprastruktur sebagai cerminan dari infrastruktur, bahkan suprastruktur harus mengakomodasikan kehidupan infrastruktur, dan sebaliknya infrastruktur sebagai replika dari suprastruktur. Menurut Robert Dahl dalam buku "Modern Political Analysis", sistem politik adalah:

"any persistent pattern of human relationship that involved to a significant of extent power, influence, control, rule or authority."

Sistem politik menurut Dahl, sebagai pola tetap hubungan manusia yang terkait berbagai kepentingan tentang kekuasaan, pengaruh, pengendalian, aturuan dan wewenang. Dari ungkapan ini, perlu dipahami tentang pola tetap, yaitu suatu pola yang telah baku dan telah menjadi standar atau ukuran dalam kehidupan negara. Pola tetap mengandung makna pula sebagai pola yang mendasar pada sistem nilai tertentu yang berlaku pada sistem tertentu pula.

Demikian halnya komunikasi politik apabila sebagai suatu sistem maka komunikasi tersebut berada pada sistem tertentu. Secara empiris, sistem komunikasi terpilah ke dalam empat sistem besar, yaitu:33

1. Komunikasi politik yang diaktualisasikan dalam sistem totaliter (authoritarianism system).

2. Komunikasi politik yang diaktualisasikan dalam sistem liberal (libertarian system).

3. Komunikasi politik yang diaktualisasikan pada negara penganut sistem tanggung jawab sosial (social responsibility).

\footnotetext{
${ }^{32}$ Soemarno AP, Komunikasi Politik, (Universitas Terbuka: 2009), hlm. 1.21

${ }^{33} \mathrm{Ibid}, \mathrm{hlm} 1.22$
} 
4. Komunikasi politik yang diaktualisasikan dalam sistem komunis.

Untuk memahami semua sistem di atas, maka bisa kita mengacu kepada pendapat Jucuis yang menyatakan bahwa: ${ }^{34}$

"komunikasi baru akan berkembang, apabila tidak terikat oleh sejumlah peraturan yang mendominasi perkembangan opini publik yang ada pada masyarakat. Komunikasi dari bawah ke atas dengan menggunakan saluran tidak resmi baru dapat berjalan apabila struktur pemerintah membuka lebar terhadap masuknya input dari bawah (infrastruktur)".

Gambaran Jucuis, hanya akan terjadi di negara-negara demokrasi yang menjunjung tinggi hak azasi, menghargai pendapat dan pemikiran orang lain. Negara yang termasuk negara demokrasi adalah seperti Amerika Serikat, Perancis, Jerman dan beberapa negara Eropa Barat. Pada negara-negara demokrasi, potensi mengarah ke demokratisasi komunikasi (democratization of communication) lebih memungkinkan, karena lembaga negara benar-benar menjalankan fungsi input sehingga terjadinya dinamika munculnya pendapat umum. Selanjutnya, demoktratisasi komunikasi ini menurut Sean MacBride memberikan batasan sebagai berikut:

"Demokrasi dapat dirumuskan sebagai suatu proses dimana: a) individu dijadikan sebagai partner yang aktif dan tidak sebagai objek komunikasi saja; b) meningkatnya pesan yang dipertukarkan; dan c) mendorong perkembangan dan kualitas komunikasi yang mewakili masyarakat." 35

Pendapat MacBride ini, memberikan suatu perspektif adanya sistem input dan output yang seimbang, dimana suprastruktur membutuhkan respons atau feedback sebagai bahan kebijakan komunikasi (communication policy). Pada negara totaliter, komunikasi hanya berjalan satu arah tanpa respons atau umpan balik (feedback) secara benar dari arah berlawanan. Sistem-sistem totaliter tidak memberi ruang adanya pusat-pusat kekuasaan lainnya, selain partai tunggal atau partai dominan. Partai tunggal akan menguasai seluruh aspek kehidupan seperti yang terjadi di Korea Utara di era sekarang (negara komunis sebagai model negara totaliter baru).

Dalam sistem demokrasi, pengelolaan sumber-sumber komunikasi dibagi ke dalam tiga fungsi kekuasaan, yaitu:

1. Eksekutif (fungsi pemerintahan).

2. Legislatif (fungsi pembentukan Undang-Undang).

3. Yudikatif (fungsi pengadilan).

Dari ketiga fungsi memang yang mempunyai pengaruh secara dominan kekuasaan adalah eksekutif dalam menjalankan roda pemerintahan, namun kedua fungsi lainnya legislative dan yudikatif mempunyai peran yang tidak

\footnotetext{
${ }^{34} \mathrm{Ibid}, \mathrm{hlm} 1.23$

35 Ibid.
} 
bisa digantikan oleh pemerintah atau fungsi-fungsi lembaga yang lainnya. Dari semua fungsi-fungsi sumber kekuasaan tersebut tidak akan bermakna bisa tidak terjadi komunikasi yang baik. Komunikasi menjadi ruh dan penggerak dari kehidupan bermasyarakat dan bernegara.

Negara akan bergerak dengan adminstrasi negera sebagai urat nadinya dan komunikasi sebagai jiwanya. Dalam mengisi struktur kekuasaan maka komunikasi berfungsi sangat efektif. Komunikasi berfungsi memotivasi dan mengkondisikan pendapat umum agar mendukung terselenggaranya pengisian struktur kekuasaan. Dalam mengisi struktur kekuasaan diselenggarakan melalui proses demokrasi yang disebut pemilihan umum. Untuk mengisi struktur perwakilan atau lembaga legislative maka rakyat memilih wakil-wakil mereka melalui pemilihan partai politik, sedangkan untuk memilih pimpinan eksekutif yaitu presiden maka rakyat memilih sistem pemerintahan presidential.

Jadi suasana komunikasi politik berada dalam dua suasana yaitu suprastruktur komunikasi dan infrastruktur komunikasi. Pada suprastruktur komunikasi terdiri dari para pengelola sumber komunikasi sesuai dengan fungsi kekuasaan. Sedangkan pada infrastruktur atau suasana komunikasi masyarakat yang terdiri dari para pengelola sumber komunikasi sesuai kebutuhan unsur-unsur yang ada pada infrastruktur. Adapun menurut G.A. Almond dan S. Coleman infrastruktur politik dikualifikasikan ke dalam lima kelompok, yaitu:

1. Partai Politik (political party).

2. Golongan Kepentingan (interest group).

3. Golongan Penekan (Pressure group).

4. Tokoh Politik (political figure), dan

5. Alat-alat (media) Komunikasi Politik (Political communication tools).

Kelima kelompok tersebut sangat berpengaruh terhadap situasi kehidupan politik, karena mereka memiliki kemampuan untuk menggerakkan massa dan mampu untuk memobilisasi pendapat umum agar berpihak kepada mereka. Karena itu elit-elit suprastruktur sangat berkepentingan untuk selalu menjalin komunikasi dengan elit-elit infrastruktur, terutama di dalam mempertahankan status kekuasaannya.

Kelompok-kelompok infrastruktur tersebut merupakan komunikatorkomunikator politik yang selalu berusaha mengembangkan pengaruh untuk mendapatkan dukungan masyarakat pada waktu terjadi pergeseran atau pergantian elit berkuasa melalui proses pemilihan umum. 


\section{Daftar Pustaka}

Achmad, Mudlor. (tanpa tahun). Etika Dalam Islam. Surabaya: Al-ikhlas.

Adji, Oemar Seno. 1973. Mass Media dan Hukum. Jakarta: Erlangga.

Ahmad, Zainal Abidin. 1974. Negara Adil Makmur Menurut Ibnu Sina. Jakarta: Bulan Bintang.

Alfian. 1991. Komunikasi Politik dan Sistem Politik Indonesia. Jakarta: Gramedia Pustaka Utama.

Al-Ghazali, Imam. 1995. Ringkasan Ihya Ulumuddin. Jakarta: Pustaka Amani.

Almond, Gabriel dan James S. Coleman [Eds.]. 1960. The Politics of the Developing Areas. Princeton University Press.

Almond, Gabriel dan Sidney Verba. 1990. Budaya Politik: Tingkah Laku Politik dan Demokrasi di Lima Negara. Jakarta: Bumi Aksara.

Alonso, Sonia. 2011. The Future of Representative Democracy. Cambridge University Press.

Arifin, Anwar. 1992. Komunikasi Politik dan Pers Pancasila. Jakarta: Media Sejahtera.

.2011. Komunikasi Politik: Filsafat, Paradigma, Teori, Tujuan, Strategi dan Komunikasi Politik Indonesia. Yogyakarta: Graha Ilmu.

Bahm, Archie J. 2003. Filsafat Perbandingan: Filsafat Barat, India, Cina dalam Perbandingan. Yogyakarta: Kanisius.

Bambang S. dan Sugianto. 2007. Pendidikan Kewarganegaraan. Surakarta: Penerbit Grahadi.

Barker, Ernest. 1962. The Politics of Aristotle. Oxford University Press.

Bastian, Indra. 2007. Akuntansi untuk LSM dan Partai Politik. Jakarta: Erlangga.

Benedict, Ruth. 2006. Patterns of Culture. Mariner Books.

Berg-Schlosser, Dirk dan Ralf Rytlewski [Eds.]. 1993. Political Culture in Germany. Palgrave Macmillan.

Bertalanffy, Ludwig Von. 2003. General System Theory: Foundations, Development, Applications. George Braziller Inc.

Bertens, K. 2000. Etika. Jakarta: Gramedia Pustaka Utama.

Blake, Reed H. dan Edwin O. Haroldsen. 2003. Taksonomi Konsep Komunikasi. Terjemahan oleh Hasan Bahanan. Surabaya: Papyrus.

Budiardjo, Miriam. 2008. Dasar-dasar Ilmu Politik. Jakarta: Gramedia Pustaka Utama.

Cangara, Hafied. 2011. Komunikasi Politik: Konsep, Teori dan Strategi. Jakarta: RajaGrafindo Persada.

Chilcote, Ronald H. 1981. Theories of Comparative Political Economy. Westview Press.

Dahl, Robert A. dan Bruce. 2002. Modern Political Analysis. Pearson. 
DeVito, Joseph A. 2011. Komunikasi Antarmanusia. Karisma Publishing.

Diamond, Larry. 2003. Dinamika Konsolidasi Demokrasi. Yogyakarta: IRE Press.

Djafar, Massa. 2015. Krisis Politik \& Proposisi Demokratisasi. Jakarta: Bumi Aksara.

Dovring, Karin. 1987. Harold Dwight Lasswell: His Communication With a Future. K. Dovring.

Easton. David. 1965. A Framework for Political Analysis. Prentice-Hall, Inc. 1965. Systems Analysis of Political Life. John Wiley \& Sons Ltd.

Erikson, Robert dan Kent L. Tedin. 2014. American Public Opinion: Its Origins, Content and Impact. Routledge.

Fagen, Richard R. 1966. Politics and Communication: An Analytic Study. Little Brown \& Company.

Faturohman, Deden dan Wawan Sobari. 2002. Pengantar Ilmu Politik. Malang: UMM Press.

Ferrari, G.R.F. 2005. City and Soul in Plato's Republic. The University of Chicago Press.

Han, Sam dan Kamaludeen Mohamed Nasir. 2015. Digital Culture and Religion in Asia. Routledge.

Hastuti, Sri [Ed.]. 2011. New Media: Teori dan Aplikasi. Surakarta: Lindu Pustaka.

Heryanto, Gun Gun dan Irwa Zarkasy. 2011. Public Relations Politik. Jakarta: Ghalia Indonesia.

Hikmat, Mahi M. 2010. Komunikasi Politik: Teori dan Praktik (Dalam Pilkada Langsung). Bandung: Simbiosa Rekatama Media.

Husaini, Adian. 2002. Penyesatan Opini: Sebuah Rekayasa Mengubah Citra. Jakarta: Gema Insani Press.

Jefkins, Frank. 2004. Public Relations (Edisi 5). Jakarta: Erlangga.

Johari, Jagdish Chandra. 1972. Comparative Politics. Sterling Publishers.

Kaid, Lynda Lee (Ed.). 2004. Handbook of Political Communication Research. Routledge.

Kantaprawira, Rusadi. 2006. Sistem Politik Indonesia: Suatu Model Pengantar. Bandung: Sinar Baru Algensindo.

Klosko, George. 2012. History of Political Theory: An Introduction: Volume I: Ancient and Medieval. Oxford University Press.

Langeveld, M.J. 1959. Menuju ke Pemikiran Filsafat. Jakarta: PT. Pembangunan.

Lasswell, Harold D. 1936. Politics: Who Gets What, When, How. Peter Smith Pub Inc.

Lasswell, Harold D. dan Abraham Kaplan. 2013. Power and Society: A Framework for Political Inquiry. Transaction Publishers.

Lippmann, Walter. 1998. Opini Umum. Jakarta: Yayasan Obor Indonesia.

Magnis-Suseno, Franz. 1992. Filsafat Sebagai Ilmu Kritis. Yogyakarta: Kanisius. 
1993. Etika Dasar: Masalah-masalah Pokok Filsafat Moral. Yogyakarta:

Kanisius.

Makmurtono, Agus dan Munawir. 1989. Etika (Filsafat Moral). Jakarta: Wira Sari.

Manheim, Karl. 1987. Sosiologi Sistematis: Suatu Pengantar Studi Tentang Masyarakat. Jakarta: Bina Aksara.

Masdar, Umaruddin [et al.]. 1999. Mengasah Naluri Publik Memahami Nalar Politik. Yogyakarta; LKiS.

McNair, Brian. 2003. An Introduction to Political Communication (Communication and Society). Routledge.

Mulyana, Deddy. 2013. Komunikasi Politik, Politik Komunikasi: Membedah Visi Dan Gaya Komunikasi Praktisi Politik. Bandung: Remaja Rosdakarya.

Nasuka. 2005. Teori Sistem Sebagai Salah Satu Alternatif Pendekatan dalam Ilmu-Ilmu Agama Islam. Jakarta: Kencana.

Nasution, Zulkarimien. 1990. Komunikasi Politik: Suatu Pengantar. Jakarta: Ghalia Indonesia.

Nimmo, Dan. 2001. Komunikasi Politik: Khalayak dan Efek. Bandung: Remaja Rosdakarya.

2006. Komunikasi Politik: Komunikator, Pesan dan Media. Terjemahan oleh Jalaluddin Rakhmat. Bandung: Remaja Rosdakarya.

Nurdin, Muslim [et al.]. 1995. Moral dan Kognisi Islam. Bandung: CV. Alfabeta.

Nurudin. 2001. Komunikasi Propaganda. Bandung: Remaja Rosdakarya.

Olii, Helena. 2007. Opini Publik. Jakarta: PT. Indeks.

Pasiak, Taufiq. 2004. Revolusi IQ/EQ/SQ: Menyingkap Rahasia Kecerdasan Berdasarkan Quran dan Teori Neurosains Mutakhir. Bandung: PT. Mizan Publika.

Patterson, Kerry dan Joseph Grenny. 2005. Crucial Conversations - Strategi Menghadapi Percakapan Berisiko Tinggi. Jakarta: Gramedia Pustaka Utama.

Peter, Laurence J. 1986. Piramida Peter: atau Mungkinkah kita Mencapai Puncaknya. Jakarta: Erlangga.

Plano, Jack C., Robert E. Riggs dan Helena S. Robin. 1989. Kamus Analisa Politik. Jakarta: Rajawali.

Purwasito, Andrik. 2011. Pengantar Studi Politik. Surakarta: UNS Press.

R. G. Meadow. 1985. Political Communication Research in the 1980s. Journal of Communication. Volume 35 Issue 1.

Ranney, Austin. 1992. Governing: An Introduction to Political Science. Prentice Hall College.

Rauf, Maswadi dan Mappa Nasrun [Eds.]. 1993. Indonesia dan Komunikasi Politik. Jakarta: Gramedia Pustaka Utama.

Reksosusilo, Stanislaus. 2005. Diktat Kuliah Filsafat Cina. Malang: STFT Widya Sasana. 
Rogers, Everett M. 2004. 'Theoritical Diversity in Political Communication'. In Lynda Lee Kaid (Ed.), Handbook Handbook of Political Communication Research. Routledge.

Rosenthal, Erwin Isak Jakob. 2009. Political Thought in Medieval Islam: An Introductory Outline. Cambridge University Press.

Ruck, Anne. 2008. Sejarah Gereja Asia. Jakarta: BPK Gunung Mulia.

Ruslan, Rosady. 2005. Kiat dan Strategi Kampanye Public Relations. Jakarta: RajaGrafindo Persada.

Sanit. Arbi. 2002. Politik, Demokrasi dan Manajemen Komunikasi. Yogyakarta: Galang Press.

Sastropoetro, Santoso. 1990. Komunikasi Sosial. Bandung: Remaja Rosdakarya.

Shahreza, Mirza. 2017. Komunikator Politik Berdasarkan Teori Generasi. Journal of Communication (Nyimak), Vol. 1, No. 1, 33-48.

Shahreza, Mirza dan Korry El-Yana. 2016. Etika Komunikasi Politik. Tangerang: Indigomedia.

Sobur, Alex. 2001. Etika Pers Profesionalisme dengan Nurani. Bandung : Humaniora Utama Press.

Soemarno dan Rochajat Harun. 2006. Komunikasi Politik: Sebagai Suatu Pengantar. Bandung: Mandar Maju.

Soemarno. 1989. Dimensi-Dimensi Komunikasi Politik. Bandung: Citra Aditya Bakti. 2009. Materi Pokok Komunikasi Politik. Jakarta: Universitas Terbuka.

Soemirat, Soleh dan Elvinaro Ardianto. 2007. Dasar-Dasar Public Relations. Bandung: Remaja Rosdakarya.

Strauss, William dan Neil Howe. 1991. Generations: The History of America's Future, 1584 to 2069. William Morrow \& Co. 1993. 13th Gen: Abort, Retry, Ignore, Fail? Vintage. . 2000. Millennials Rising: The Next Great Generation. Vintage.

Suhandang, Kustadi. 2004. Pengantar Jurnalistik: Seputar Organisasi, Produk dan Kode Etik. Bandung: Nuansa Cendekia.

Suito, Deny. 2006. Membangun Masyarakat Madani. Jakarta: Centre For Moderate Muslim Indonesia.

Surbakti, Ramlan. 1992. Memahami Ilmu Politik. Jakarta: Grasindo.

Susanto, Astrid, S. 1985. Komunikasi Sosial di Indonesia. Bandung: Binacipta.

Suwardi, Arsono [et al.]. 2002. Politik, Demokrasi \& Manajemen Komunikasi. Yogyakarta: Galang Press.

Syah, Sirikit. 2014. Membincang Pers: Kepala Negara dan Etika Media. Jakarta: Elex Media Komputindo. 
Tabroni, Roni. 2012. Komunikasi Politik Pada Era Multimedia. Bandung: Simbiosa Rekatama.

Tamburaka, Apriadi. 2013. Literasi Media: Cerdas Bermedia Khalayak Media Massa. Jakarta: Rajawali Pers.

Thompson, George Carslake. 2012. Public Opinion and Lord Beaconsfield (Volume 1). Ulan Press.

Tocqueville, Alexis de. 1990. Democracy in America, Volume 1. Vintage.

Tubbs, Stewart L. dan Sylvia Moss. 2001. Human Communication: Konteks-Konteks Komunikasi (Buku 1). Bandung: Remaja Rosdakarya.

Umary, Barnawie. 1993. Materia Akhlak. Solo: Ramadhani.

Varma, SP. 1995. Teori Politik Modern. Jakarta: RajaGrafindo Persada.

Weber, Max [et al.]. 1947. The Theory of Social and Economic Organization. Oxford University Press.

West, Richard dan Lynn H. Turner. 2008. Pengantar Teori Komunikasi: Analisis dan Aplikasi (Buku 1). Jakarta: Salemba Humanika.

Wibowo, Eddi [et al.]. 2004. Ilmu Politik Kontemporer. Yogyakarta: YPAPI.

Wiseman, H. Victor. 1966. Political Systems : Some Sociological Approaches. Praeger.

Young, Oran R. 1968. Systems of Political Science (Foundations of Modern Political Science Series). Prentice-Hall.

Yu-Lan, Fung. 2007. Sejarah Filsafat Cina. Yogyakarta: Pustaka Pelajar.

\section{Tentang penulis}

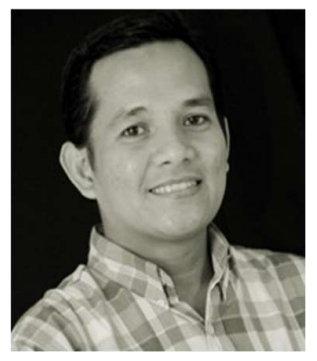

Mirza Shahreza, S.I.Kom, M.I.K. Lahir di Jakarta, 29 Juli 1976. Bertempat tinggal domisili di daerah Rempoa, Tangerang Selatan, Banten. Menyelesaikan S1 IImu Komunikasi dari Universitas Terbuka (UT) pada tahun 2012 dan S2 Komunikasi Politik pada Sekolah Pascasarjana Universitas Muhammadiyah Jakarta (UMJ) pada tahun 2014. Saat ini sebagai dosen tetap di Fakultas IImu Sosial dan IImu Politik (FISIP) Universitas Muhammadiyah Tangerang (UMT).

Pengalaman mengajar pernah mengampu mata kuliah komunikasi politik, Komunikasi massa, komunikasi antar budaya dan Teori Komunikasi pada Universitas Muhammadiyah Tangerang (2014 - sekarang) dan FISIP Universitas Pembangunan Nasional "Veteran" Jakarta (UPNVJ) (2012-2015). Saat ini sedang menempuh pendidikan pascasarjana S3 Komunikasi Pembangunan Pedesaan dan Pertanian di Institut Pertanian Bogor angkatan 2017.

Keterlibatan dalam organisasi menjadi pengurus Ikatan Sarjana Komunikasi Indonesia (ISKI) Pusat sebagai wakil ketua bidang keanggotaan periode 2013 - 2017, sebagai ketua dewan Pembina Yayasan Desa Hijau (YDH) sejak 2011 - sekarang, dan kordinator Association of The Creator's Code Breakers (ACCB) sejak 2009 - sekarang. 


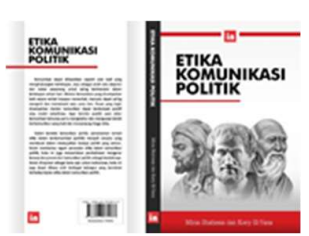

